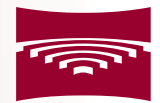
Rīgas STRADIN̦A UNIVERSITĀTE

\title{
Artis Kalniņ̧̌
}

\section{Koronārās sirds slimības ārstēšanas metožu salīdzinājums pacientiem ar hroniskām totālām koronāro artēriju oklūzijām}

Promocijas darba kopsavilkums zinātniskā doktora grāda "zinātnes doktors (Ph.D.)" iegūšanai

Nozare - klīniskā medicīna Apakšnozare - kardiologijija 


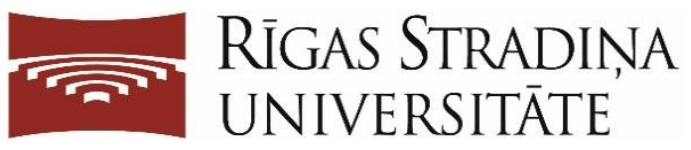

\author{
Artis Kalniņšs \\ ORCID 0000-0001-8906-0111
}

Koronārās sirds slimības

ārstēšanas metožu salīdzinājums pacientiem ar hroniskām totālām koronāro artēriju oklūzijām

Promocijas darba kopsavilkums zinātniskā doktora grāda "zinātnes doktors (Ph.D.)" iegūšanai

Nozare - klīniskā medicīna

Apakšnozare - kardiologija

Rīga, 2021 
Promocijas darbs izstrādāts Rīgas Austrumu klīniskajā universitātes slimnīcā, stacionārā "Gaiḷezers", Latvijā

Promocijas darba vadītāji:

Dr. med. LZA īstenais loceklis Aivars Lejnieks, Rīgas Stradiṇa universitāte, Latvija

Dr. med. LZA īstenais loceklis Andrejs Ērglis, Latvijas Universitāte

Oficiālie recenzenti:

Dr. med. profesors Oskars Kalējs,

Rīgas Stradiņa universitāte,

P. Stradiṇa Klīniskā universitātes slimnīca, Latvija

Dr. med. Ainārs Rudzītis,

Latvijas Universitāte,

P. Stradinna Klīniskā universitātes slimnīca, Latvija

Ph.D. profesors Sergey Furkalo,

Nacionālais ķirurǵijas un transplantoloǵijas institūts, Kijeva, Ukraina

Promocijas darbs tiks aizstāvēts Rīgas Stradina universitātes Klīniskās medicīnas promocijas padomes atklātā sēdē 2021. gada 16. decembrī plkst. 15.00 tiešsaistes platformā Zoom.

Ar promocijas darbu var iepazīties RSU bibliotēkā un RSU tīmekḷa vietnē: https://www.rsu.lv/promocijas-darbi

Promocijas padomes sekretāre:

Dr. med. asociētā profesore Ilze Konrāde 


\section{Satura rādītājs}

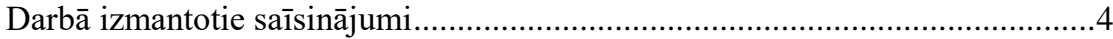

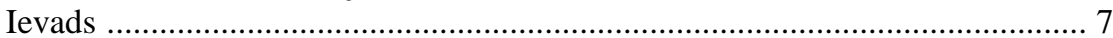

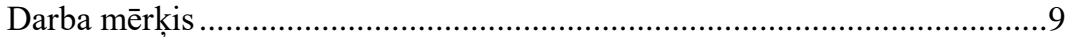

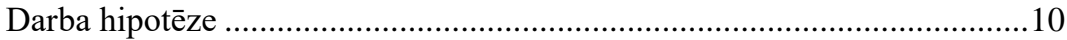

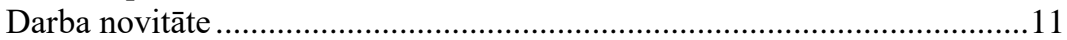

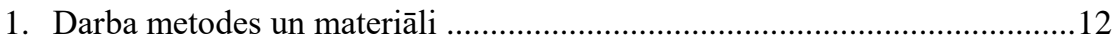

1.1. Reǵistrā iekḷauto pacientu un procedūras raksturojums .................... 12

1.1.1. Reǵistrā iekḷauto pacientu demogrāfiskais un klīniskais raksturojums .................................................................... 12

1.1.2. Koronārās anatomijas un hroniskās totālās koroārās

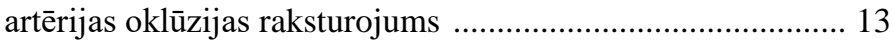

1.1.3. Perkutānās koronārās intervences apraksts ............................. 14

1.1.4. Perkutānās koronārās intervences rezultāti ............................ 15

1.1.5. Hronisku totālu koronāro artēriju oklūziju sarežğīīības

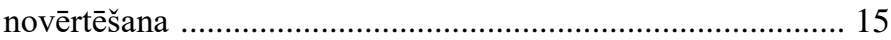

1.2. Reǵistrā iekḷauto pacientu iedalījums apakšgrupās ............................15

1.3. Statistiskās datu apstrādes metodes ....................................................17

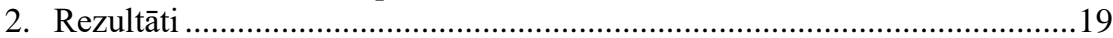

2.1. Sekmīgo un nesekmīgo procedūru salīdzinājums ..............................20

2.2. Izdzīvotība pēc sekmīgām un nesekmīgām procedūrām dažādām

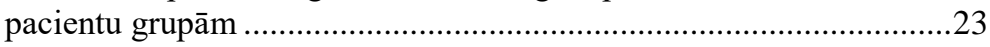

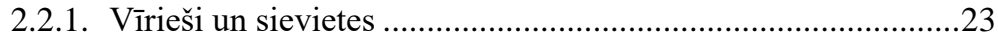

2.2.2. Pacienti līdz 65 gadu vecumam un vecāki.............................25

2.2.3. Pacienti ar cukura diabētu un bez tā ......................................26

2.2.4. Pacienti, kam veikta koronāro artēriju šuntēšanas operācija anamnēzē, un pacienti, kam tās nav bijis ............... 29

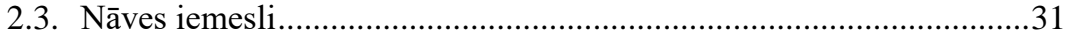

2.4. Antegrādās un retrogrādās metodes lietošana .....................................33

2.5. Hronisku totālu koronāro artēriju oklūziju sarežǵîtības, kas novērtēta pēc dažāāām skalām, saistība ar PKI rezultātiem ................36

2.6. Komplikācijas ................................................................................43

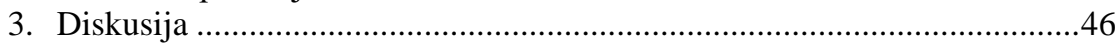

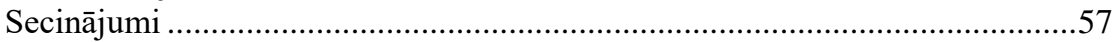

Publikācijas un ziņojumi par promocijas darba tēmu ......................................59

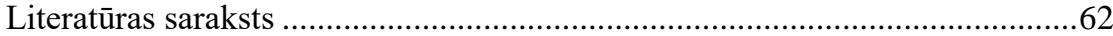

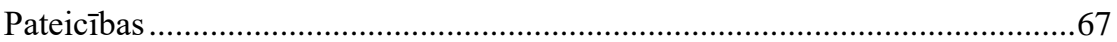




\section{Darbā izmantotie saīsinājumi}

ACC

ADR

AHA

AUC

BASE

BMI

BMS

BVS

CART

CASTLE score

CC

CFI

CHD

CL

CTO

CVP

DATT
Amerikas Kardioloǵijas koledža (angl. American College of Cardiology)

antegrādā disekcija-atgriešana (angl. antegrade dissection re-entry)

Amerikas Sirds asociācija (angl. American Heart Association)

laukums zem līknes (angl. area under curve)

balona atbalstīta subintimāla iekḷūšana (angl. balloon assisted subintimal entry)

ķermeņa masas indekss (angl. body mass index)

parastie metāla stenti (angl. bare metal stent)

bioabsorbējošs stents

(angl. bioresorbable vascular scaffold)

kontrolēta antegrādā un retrogrādā šḳērsošana (angl. Controled antegrade and retrograde tracking)

hroniskas totālas koronārās artērijas oklūzijas sarežğîtības vērtēšanas skala (angl.: CABG history, Age ( $\geq 70 y r s)$, Stump anatomy (blunt or invisible), Tortuosity degree (severe or unseen), Length of occlusion ( $\geq 20 \mathrm{~mm}$ ) and Extent of calcification (severe)),

kolaterāḷu savienojums (angl. collateral connection)

kolaterālās plūsmas indekss (angl. collateral flow indekss)

koronārā sirds slimība (angl. coronary heart disease)

hroniskas totālas koronārās artērijas oklūzijas sarežgiîtības vērtěšanas skala (angl.: The Clinical and Lesion related score)

hroniska totāla oklūzija (angl. Chronic Total Occlusion)

centrālais venozais spiediens

duālā antitrombotiskā terapija 
DECISION CTO pētījums (angl. Drug-Eluting Stent Implantation Versus Optimal Medical Treatment in Patients with Chronic Total Occlusion)

DES

EKG

ESC

FFR

HR

IVUS

$\mathrm{J}-\mathrm{CTO}$ score

KAŠ

KSS

LAD

LCX

LIMA

LM

LVEF

MACE

MI

MR

MPS

MSCT

OAT ar zālēm pildīts stents (angl. drug eluting stent)

elektrokardiogramma

Eiropas Kardiologu biedrība (angl. European Society of Cardiology)

frakcionētā plūsmas rezerve (angl. fractional flow reserve)

draudu attiecība (angl. hazard ratio)

intravaskulāra ultraskaņa (angl. intra vascular ultrasound)

hroniskas totālas koronārās artērijas oklūzijas sarežğîtības

vērtēšanas skala (angl. Multicenter Chronic Total

Occlusion (CTO) Registry in Japan)

koronāro artēriju šuntēšana

koronārā sirds slimība

kreisā priekšējā lejupejošā koronārā artērija

(angl. left anterior descendens artery)

kreisā apliecošā koronārā artērija

(angl. left circumflex artery)

kreisā iekšèjā mammārā artērija

(angl. left internal mammary artery)

kreisās koronārās artērijas kopējais stumbrs (angl. left main)

kreisā kambara izsviedes frakcija

(angl. left ventricul ejection fraction)

nozīmīgi nelabvēlīgi kardiāli notikumi

(angl. major adverse cardiac events)

miokarda infarkts

magnētiskā rezonance

miokarda perfūzijas scintigrāfija

daudzslāņu datortomogrāfija

(angl. multi-slice computer tomography)

pētījums (angl. Occluded Artery Trial) 
$\mathrm{OM}$

PKI

POBA

PROGRESS CTO hroniskas totālas koronārās artērijas oklūzijas sarežǵîtības vērtēšanas skala (angl. Prospective Global Registry for the study of Chronic Total Occlusion Intervention)

RCA

RDR

REVASC

ROC līkne

SAQ

SD

SE

SSK

STAR

STEMI

SYNTAX

TI

TIMI

VEM trulās malas zars

perkutāna koronāra intervence (angl. percutaneous coronary intervention) labā koronārā artērija (angl. right coronary artery) retrogrādā disekcija-atgriešana (angl. retrograde dissection-reentry) pētījums (angl. Recovery of Left Ventricular Function in Coronary Chronic Total Occlusion) līkne (angl. Receiver Operating Characteristic) dzīves kvalitātes vērtēšanas anketa (angl. Seattle Angina Questionnaire) standartnovirze (angl. standart deviation) standartkḷūda (angl. standart error) Starptautiskā statistiskā slimību un veselības problēmu klasifikācija

subintimāla šḳērsošana un atgriešanās (angl. subintimal tracking and re-entry)

ST segmenta elevāciju miokarda infarkts pētijums (angl. The SYNergy between PCI with TAXus and cardiac surgery) ticamības intervēls koronārās plūsmas novērtēšanas sistēma (angl.Trombolysis in Myocardial Infarction)

veloergometrija 


\section{Ievads}

Sirds un asinsvadu slimības ir galvenais nāves cēlonis visā pasaulē. Katru gadu gandrīz 18 miljonu cilvēku nāves gadījumu iemesls ir saistīts ar artēriju aterosklerozi (Roth et al., 2017). Skatoties globāli, vērojama izteikta dažādu pasaules reǵionu atšķ̧irība sirds un asinsvadu slimību mirstības rādītājos. Ziemeḷamerikā un Rietumeiropā / Ziemel̦eiropā tie ir ievērojami zemāki nekā Austrumeiropāa Āzijā un Āfrikā. Piemēram, Francijā vecuma standartizētais mirstības rādītājs 2017. gadā bija aptuveni 86 uz 100000 iedzīvotāju; Austrumeiropā kopumā šis rādītājs bija apmēram piecas reizes lielāks - 400-500 uz 100000 iedzìvotāju. Latvijā asinsrites sistēmas slimības jau daudzu gadu garumā ir biežākais nāves cēlonis un tas ievērojami pārsniedz tādus iemeslus kā ḷaundabīgi audzēji vai ārēji izraisītie nāves cēloṇi (Latvijas veselības aprūpes statistikas gadagrāmata, 2018). Lielākā kardiovaskulārās mirstības daḷa ir tieši koronārās sirds slimības (KSS) dēḷ, kas, neraugoties uz daudzās pasaules valstīs un arī Latvijā panākto mirstības samazināšanos, joprojām ir galvenais priekšlaicīgas nāves iemesls.

Viena no KSS ārstēšanas metodēm ir perkutānā koronārā intervence (PKI). Tā ir salīdzinoši jauna ārstēšanas metode, par kuras pamatlicēju uzskata Andreas Gruntzig, kurš 1977. gadā veica pirmo koronāro balona angioplastiku (POBA, plain old balloon angioplasty). Turpmākajos gados PKI tehnologijas strauji attīstījās, balona angioplastikai sekoja stentu implantācijas ēra, kas sākās ar parastajiem metāla stentiem (BMS, bare metal stent). Pirmo koronāro angioplastiku ar stenta implantāciju 1987. gadā veica Ulrich Sigwart (Roubin, 2014). 2002. gadā klīniskajā praksē ienāca zālēm pārklātie vai pildītie stenti (DES, drug eluting stent), kas tiek uzskatīts par vienu no lielākajiem sasniegumiem PKI jomā. DES lietošana ievērojami samazināja parasto metāla stentu bieži izraisīto restenozi. Tomēr grūtības no invazīvās ārstēšanas viedokḷa joprojām rada anatomiski sarežg̀īti bojājumi-garas, kalcinētas stenozes, 
hroniskas totālas oklūzijas, bojājumi, kas lokalizēti artēriju bifurkācijās, mazo artēriju slimība u. c. Koronāro artēriju bojājuma variants, kas joprojām ir viens no lielākajiem izaicinājumiem invazīvo kardiologu sabiedrībai, ir hroniskas totālas koronāro artēriju oklūzijas (HTO).

HTO sastopamas samērā bieži - vidēji 30 \% gadījumu no pacientiem ar angiogrāfiski pierādītu nozīmīgu koronāro artēriju slimību (Christofferson et al., 2005). Šo bojājumu ārstēšana ir problemātiska, jo procedūras ir tehniski sarežǵītas, materiālu un laika ietilpīgas, sekmīgo perkutāno koronāro intervenču skaits procentuāli ir relatīvi zems, ir paaugstināts iespējamo komplikāciju skaits hospitālajā periodā, kā arī ilgtermiņa rezultāti ir sliktāki, salīdzinot ar neokluzīvu bojājumu ārstēšanu (Shahet al., 2011). Pacienti ar HTO parasti ir vecāki, viniem ir vairāk blakus slimību un sliktāka kreisā kambara kontraktilitāte (Christofferson et al., 2005; Fefer et al., 2012; Jeroudi et al., 2014).

Pirmā perkutānā koronārā intervence izmantojot balonu hroniski okludētai koronārajai artērijai tika izdarīta 1984. gadā (Stein et al., 1984). Veicot procedūras ar tradicionālo antegrādo metodi, sekmīgo procedūru skaits parasti nepārsniedz 65-70 \% (Ruocco et al., 1992; Ivanhoe et al., 1992). Lietojot retrogrādo metodi, sekmīgo HTO PKI skaits centros ar lielu šīs metodes lietošanas pieredzi sasniedz 80-100 \% (Karmpaliotis, 2012). Kopš 1990. gadā tika publicēts pirmais ziņojums par retrogrādu HTO atvēršanu caur vēnas šuntu (Kahn et al.,1990), šī metode ir ievērojami attīstījusies. Pēdējo piecu gadu laikā praksē ieviesti gan daudzi jauni materiāli (stīgas, baloni, mikrokatetri), gan arī izstrādātas jaunas tehnikas, kas speciāli radītas HTO retrogrādas rekanalizācijas rezultātu uzlabošanai (Surmely, 2006; Saito, 2009; Kimura, 2009; Tomasello, 2014). Veicot vairāku retrospektīvu registru metaanalīzi, konstatēts, ka sekmīga HTO rekanalizācija samazina stenokardijas lēkmju biežumu, uzlabo kreisā kambara funkciju, palielina dzīvildzi un samazina fatālu aritmiju risku (Joyal, 2010). Kaut arī vairāku reǵistru dati uzrāda mirstības samazināšanos sekmīgi 
atvērtu HTO grupā, randomizētos pētījumos šāds ieguvums no HTO invazīvas rekanalizācijas, salīdzinot ar medikamentozu terapiju vai salīdzinot ar aortokoronāru šuntēšanu, nav pierādīts (Nombela-Franco, 2012).

Latvijā pirmā sekmīgā retrogrādā HTO perkutānā koronārā intervence veikta 2007. gadā slimnīcā “Gaiḷezers” (Kalnins et al., 2013). Kopš 2007. gada Gaiḷezera slimnīcā izveidots šo procedūru un pacientu reǵistrs. 2008. gadā tika izveidots Eiropas Oklūziju klubs (Euro CTO Club), lai apkopotu jaunāko informāciju par HTO invazīvu ārstēšanu, kā arī lai invazīvie kardiologi varētu apmainīties pieredzē par HTO PKI procedūru tehniskajiem aspektiem. HTO kluba darbā jau no dibināšanas gada iesaistījušies arī Latvijas kardiologi, un kopš 2011. gada lielākā daḷa Latvijā veikto HTO PKI tiek ievadītas vienotajā Eiropas Oklūziju kluba reg̣istrā.

Nav šaubu, ka daḷai HTO pacientu revaskularizācija vai rekanalizācija nemaina ilgtermiņa prognozi un dažiem pacientiem var to pat pasliktināt, īpaši, ja tiek veiktas tehniski sarežgītas procedūras ar augstu komplikāciju risku. Šobrīd, laikā, kad HTO anatomiskā sarežğîtība vairs nav šķērslis PKI veikšanai, svarīgi identificēt gan pacientus, kuriem sagaidāms labs procedūras rezultāts, gan arī tos, kuriem ieguvuma var nebūt.

\section{Darba mērḳis}

Pētījuma mērḳis ir invazīvas ārstēšanas metožu ilgtermiṇa rezultātu salīdzinājums pacientiem ar koronāro sirds slimību un hroniskām totālām koronāro artēriju oklūzijām.

\section{Promocijas darba mērḳa sasniegšanai izvirzīti šādi uzdevumi:}

1. Salīdzināt ilgtermiṇa izdzīvotības rezultātus pacientiem pēc sekmīgām un pēc nesekmīgām hronisku totālu koronāro artēriju oklūziju perkutānām koronārām intervencēm. 
2. Veikt antegrādas un retrogrādas perkutānās koronārās intervences tehnikās veikto procedūru ilgtermiṇa rezultātu salīdzinājumu hronisku totālu koronāro artēriju oklūziju pacientiem un noskaidrot visu veidu anatomiskos, morfologiskos un funkcionālos aspektus, kad var sākt hronisku totālu koronāro artēriju oklūziju perkutāno koronāro intervenci ar retrogrādo pieeju.

3. Izvērtēt hronisku totālu koronāro artēriju oklūziju sarežḡîtības daudzfaktoru ietekmi uz perkutānās koronārās intervences rezultātu un izdzìvotību.

4. Izpētīt un novērtēt hronisku totālu koronāro artēriju oklūziju perkutāno koronāro intervenču rezultātus dažādām pacientu grupām:

- pacientiem ar cukura diabētu un bez tā,

- pacientiem līdz 65 gadu vecumam un vecākiem,

- vīriešiem un sievietēm,

- pacientiem, kam veikta koronāro artēriju šuntēšanas operācija anamnēzē, pacientiem, kam tā nav bijusi.

\section{Darba hipotēze}

- Pirmā hipotēze - sekmīga hronisku totālu koronāro artēriju oklūziju invazīva rekanalizācija neatkarīgi no tās sarežğìtības un neatkarīgi no izmantotās perkutānās koronārās intervences tehnikas ir efektīva hronisku totālu koronāro artēriju oklūziju ārstēšanas metode un uzlabo pacientu dzīvildzi.

- Otrā hipotēze - retrogrādās metodes lietošana uzlabo hronisku totālu koronāro artēriju oklūziju perkutānās koronārās intervences rezultātus, nepasliktina ilgtermiņa prognozi un atsevišķos gadījumos lietojama kā primārā perkutānās koronārās intervences stratēgija. 


\section{Darba novitāte}

Pēc statistikas datiem, 5-10\% no visām perkutānām koronārām intervencēm tiek veiktas hroniskām totālām oklūzijām. Latvijā šādu operāciju ilgtermiņa rezultāti nav tikuši pētīti un zinātniskajā literatūrā to rezultāti un lietderība ir pretrun̄̄gi vērtēti. 


\section{Darba metodes un materiāli}

Zinātniskais darbs tika veikts Rīgas Austrumu klīniskās universitātes slimnīcas Sirds asinsvadu slimību klīnikā. 2007. gadā tika izveidots Hronisku totālu koronāro artēriju oklūziju invazīvas ārstēšanas reǵistrs. 10 gadu laikā līdz 2016. gada 31. decembrim reǵistrā tika iekḷauts 551 pacients. Visi pacienti bija parakstījuši slimnīcas administrācijas apstiprinātu informētu piekrišanu PKI procedūrai.

\subsection{Reǵistrā iekḷauto pacientu un procedūras raksturojums}

\subsubsection{Reǵistrā iekḷauto pacientu demogrāfiskais un klīniskais raksturojums}

Par visiem reǵistrā iekḷautajiem pacientiem tika apkopota detalizēta demogrāfiskā, klīniskā un anamnēzes informācija:

- vecums (gadi),

- dzimums (vīrietis, sieviete),

- $\operatorname{augums}(\mathrm{cm})$, svars $(\mathrm{kg}), \mathrm{KMI}$,

- smēķēšana (nekad nav smēķējis, atmetis, aktīvs smēķētājs),

- cukura diabēts (nav, insulinējams, neinsulinējams),

- dislipidēmija (nav, ir),

- HOPS (nav, ir),

- $\quad$ arteriālā hipertensija (nav, ir),

- pārciests galvas smadzeņu insults (nav, ir),

- perifēro artēriju slimība (nav, ir),

- miokarda infarkts anamnēzē (nav, ir),

- KAŠ anamnēzē (nav, ir),

- PKI anamnēzē (nav, ir; ja ir, vai tā veikta HTO asinsvadam),

- stenokardija (nav, ir), 
- elpas trūkums (nav, ir),

- EKG (izmaiņas HTO zonā - nav, ir ne Q izmaiņas, ir Q zobi, EKG nav izvērtējama),

- Eho KG (kreisā kambara izsviedes frakcija, ir vai nav izmaiņas HTO zonā),

- miokarda išēmija (pārbaude nav veikta, nav pierādīta, ir pierādīta, neskaidra),

- miokarda dzīvotspējas pierādījumi (nav Q zobu EKG, MPS, MR).

\subsubsection{Koronārās anatomijas un HTO raksturojums}

- cik koronārās artērijas bojātas (1,2 vai 3),

- HTO artērija (LAD, LCX, RCA, cita),

- HTO lokalizācija (ostiāla, proksimāla, vidējās daḷas, distāla),

- iesaistīto segmentu daudzums (viens, vairāki),

- vai HTO ietver bifurkācijas zonu (nē, jā),

- HTO ilgums (ja ir nosakāms, tad izteikts mēnešos vai nenosakāms),

- HTO ilguma noteikšanas metode (angiogrāfiski, klīniski, vizuāli),

- HTO asinsvada izlocījums (nav, neliels, izteikts, loti izteikts),

- kalcinoze (nav, neliela, izteikta, loti izteikta),

- HTO asinsvada diametra vizuāls novērtējums (mm),

- HTO garuma vizuāls novērtējums (mm),

- proksimālās ieejas novērtējums (smaila, trula, nav nosakāma),

- distālā segmenta novērtējums (neizmainīts, stenozēts, izteikti stenozēts),

- distālā segmenta pildījums (labs, nepiln̄̄gs, nav redzams),

- kolaterāles (septālas, epikardiālas, ipsilaterālas),

- kolaterāḷ novērtējums pēc CC sistēmas (CC0, CC1, CC2), 
- iepriekšējie HTO PKI mēǵinājumi (nav, ir),

- HTO sarežğîtības novērtējums punktos (pēc J-CTO, Progress, CASTLE, CL novērtēšanas sistēmām).

\subsubsection{Perkutānās koronārās intervences apraksts}

Reǵistrā apkopota detalizēta informācija par HTO PKI procedūru:

- PKI datums,

- plānotā un aktuālā pieeja (primāra antegrāda, primāra retrogrāda, anteretrogrāda, retro-antegrāda),

- vadītājzondes diametrs (Fr),

- kontralaterālās injekcijas (nav, ir veiktas),

- mikrokatetru un speciālu ierīču lietošana,

- izmantoto koronāro stīgu skaits,

- $\quad$ stīgu nosaukumi, kas tieši izmantotas kolaterāḷu un HTO šḳērsošanai,

- izmantoto balonu skaits un balona nosaukums, kas tieši izmantots HTO šķērsošanai,

- implantēto stentu skaits un izmēri,

- atlieku stenoze, koronārā plūsma, procedūru beidzot (TIMI 0, TIMI 1, TIMI 2, TIMI 3),

- HTO PKI iznākums (sekmīgs, nesekmīgs),

- procedūras kopējais ilgums (minūtes),

- rentgena starojuma laiks (minūtes),

- pacienta saņemtais starojums (greji),

- izmantotā kontrasta daudzums (ml),

- komplikācijas,

- analīžu rezultāti 48 stundu laikā pēc procedūras. 


\subsubsection{Perkutānās koronārās intervences rezultāti}

Reǵistrā tika uzskaitîta visa informācija par procedūras tehniskajiem rezultātiem un klīniskajiem iznākumiem hospitālajā periodā. 2019. gadā pacienti tika apsekoti, iegūstot datus no Slimību profilakses un kontroles centra, kā arī no Nacionālā veselības dienesta. Tika iegūta informācija par mirušajiem pacientiem, nāves iestāšanās datumu un nāves iemesliem, kas šifrēti atbilstoši SSK-10 klasifikācijai.

\subsubsection{HTO sarežğîtības novērtēšana}

Visiem pacientiem retrospektīvi tika veikts HTO novērtējums pēc 4 dažādām HTO sarežğîitības vērtēšanas sistēmām (J-CTO score, PROGRESS CTO score, CL score, CASTLE score), kas pamatojas uz angiogrāfijas un klīniskajiem datiem.

\subsection{Reǵistrā iekḷauto pacientu iedalījums apakšgrupās}

Lai izvērtētu hronisku totālu koronāro artēriju oklūziju invazīvās ārstēšanas rezultātus un tendences, regiistra ietvaros tika izveidotas vairākas pacientu apakšgrupas:

1. Pacientu grupas ar sekmīgu un nesekmīgu procedūras rezultātu.

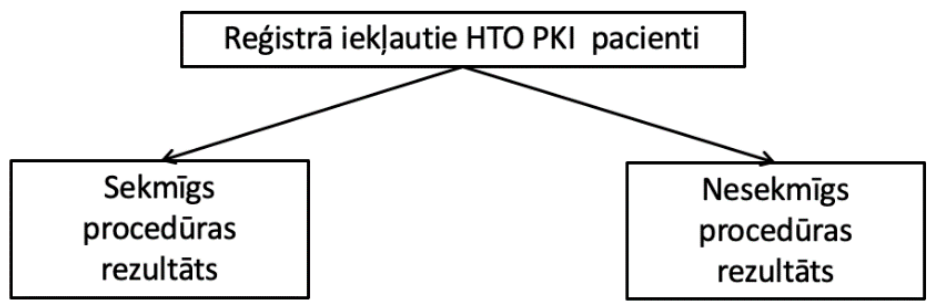

1.1. attēls. HTO PKI pacientu sadalījums pēc procedūras rezultāta 
2. Pacientu grupas, kuriem lietota tikai antegrādā un kuriem lietota retrogrādā metode.

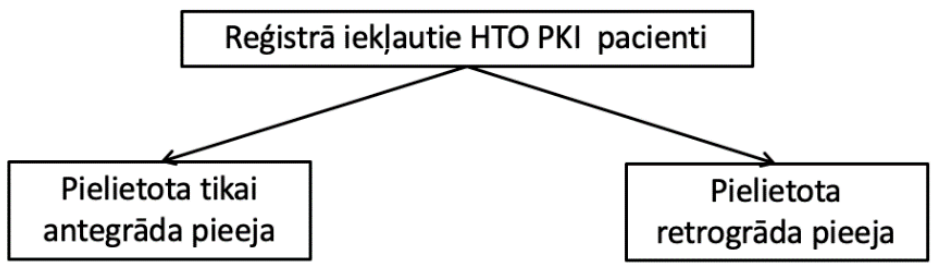

\section{2. attēls. HTO PKI pacientu sadalījums pēc izmantotās pieejas}

3. Izdalītas pacientu grupas ar zemu, vidēju un augstu sarežğîtības līmeni, vērtējot pēc 4 dažādām skalām.

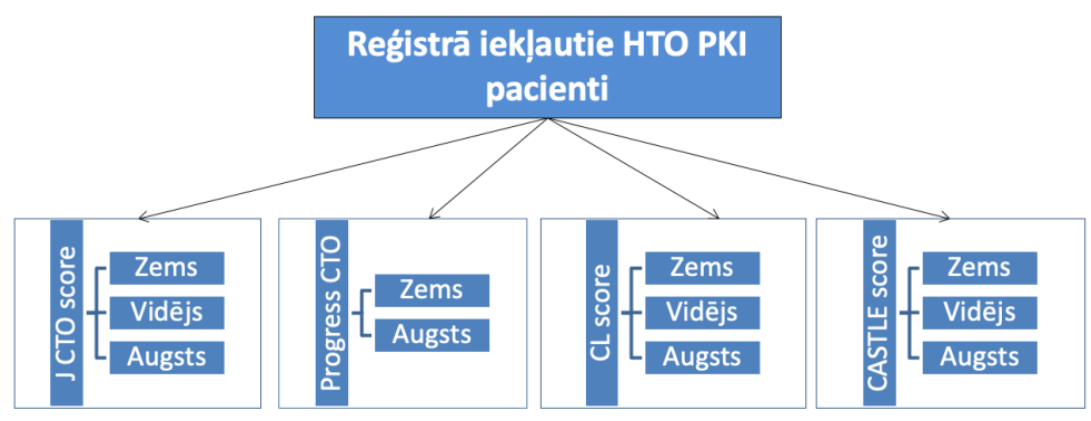

\section{3. attēls. HTO PKI pacientu iedalījums apakšgrupās}

4. Atsevišḳi analizētas dažādas pacientu apakšgrupas: vīrieši un sievietes, pacienti pirms un pēc 65 gadu vecuma, pacienti ar un bez cukura diabēta, pacienti, kuriem iepriekš bijusi veikta koronāro artēriju šuntēšanas operācija, un pacienti, kuriem šādas operācijas anamnēzē nav bijis. 


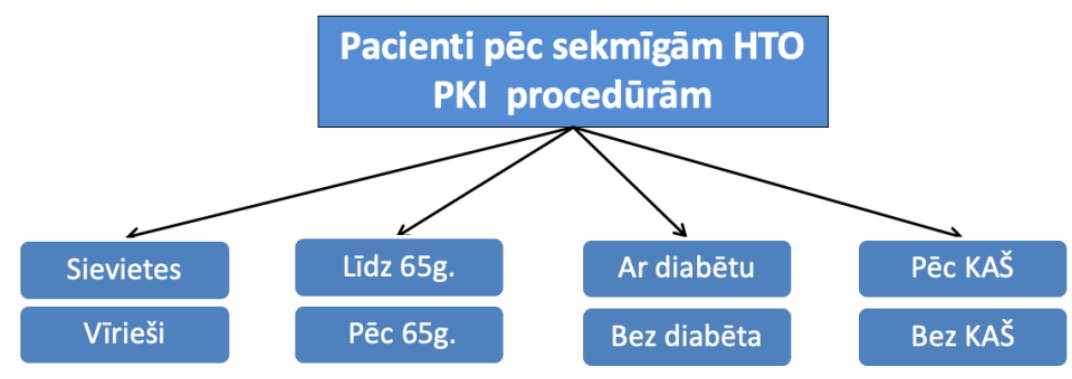

\section{4. attēls. Pacientu pēc sekmīgām HTO PKI iedalījums apakšgrupās}

\subsection{Statistiskās datu apstrādes metodes}

Datu statistiskā apstrāde tika veikta, izmantojot datorprogrammas SPSS un Microsoft Office Excel. Pacientu parametru raksturošanai izmantotas vispārpieņemtās aprakstošās statistikas metodes - kopsavilkuma tabulas kopā ar stabiṇu joslu grafikiem vai histogrammām. Tika izvērtēts centrālās tendences rādītājs (vidējais aritmētiskais un izkliedes rādītājs - standartnovirze (SD)). Bet, ja dati neatbilda normālam sadalījumam, mediāna ar starpkvartịḷu intervālu (IQR). Dihotomiem un kategoriskiem mainīgajiem tika rēķinātas proporcijas (\%) un $95 \%$ ticamības intervāls (TI) proporcijām. Proporcijas apakšgrupās tika salīdzinātas ar $h \bar{l}$ kvadrāta testu, vidējie aritmētiskie lielumi - ar divpusējo t-testu, main̄̄gie, kas neatbilda normālsadalījumam - ar Manna-Vitnija U testu.

Dzīvildzes analīze tika veikta ar Kaplana-Meiera metodi un ar Koksa regresiju. Novērošanas laiks sākās procedūras veikšanas dienā, bet beidzās - nāves dienā vai 2019. gada 31. decembrī. Tika aprēķināta izdzīvojušo pacientu daļa \% un standartkḷūda (SE) noteiktos laika periodos pēc procedūras. Kaplana-Meiera izdzīvotības līkṇu salīdzināšanai starp apakšgrupām tika izmantots log-rank tests. Koksa regresijā tika veikts vairāku faktoru ietekmes uz izdzīvotību novērtējums, tos savstarpēji samērojot. Pieņēmums par nāves riska proporcionalitāti tika pārbaudīts, vizuāli novērtējot log-log līknes, un būtiskas novirzes no proporcionalitātes netika novērotas. Faktoru saistība ar izdzīvotību 
Koksa regresijas modelī tika izteikta ar draudu attiecības (Hazard Ratio) palīdzību. HTO sarežgî̀īibas saistība ar procedūras sekmīgu vai nesekmīgu rezultātu tika novērtēta ar ROC līknēm, aprēkinot laukumu zem līknes (AUC) ar $95 \%$ TI. Par statistiski nozīmīgu tika pieņemta p vērtība $<0,05$. 


\section{Rezultāti}

No 2007. gada 1. janvāra līdz 2016. gada 31. decembrim RAKUS Gaiḷezera slimnīcas HTO reǵistrā iekḷauts 551 pacients, kam tika veiktas HTO PKI. Vidējais pacientu vecums bija 63,5 (+ / -10,4) gadi, un 80 \% pacientu bija vīrieši. 4,5\% anamnēzē bija veikta koronāro artēriju šuntēšanas operācija (KAŠ), bet 52,5 \% iepriekš bijusi veikta PKI. 20 \% pacientu bija diabēts, 72,6 \% anamnēzē pārciests miokarda infarkts (sk. 2.1. tabulu).

Pacienti tika sadalīti divās grupās pēc HTO PKI procedūras rezultāta - sekmīgu gadījumu grupa $(\mathrm{N}=454)$ un nesekmīgu gadījumu grupa $(\mathrm{N}=97)$. Tāpat pacienti sadalīti grupās pēc lietotās tehnikas - antegrādās metodes grupā $(\mathrm{N}=368)$ un retrogrādās metodes grupā $(\mathrm{N}=183)$. Atsevišķi analizētas arī citas pacientu grupas: vīrieši un sievietes, pacienti ar un bez cukura diabēta, pacienti ar un bez KAŠ operācijas anamnēzē, pacienti līdz 65 gadu vecumam un vecāki.

Visi pacienti pirms procedūras saņēma aspirīnu un P2Y12 receptoru inhibitoru (klopidogrelu). Katram pacientam procedūras sākumā tika ievadīts 5000 vienību heparīna. Katru stundu tika injicētas papildus 2500 vienību. Aktivētais recēšanas laiks (ACT) netika kontrolēts. Nevienā no procedūrām netika izmantoti glikoproteīdu $2 \mathrm{~B} 3 \mathrm{~A}$ receptoru blokatori.

J-CTO, PROGRESS CTO, CL un CASTLE rādītāji tika aprēḳināti retrospektīvi, pamatojoties uz koronāro angiogrāfiju un medicīnisko dokumentāciju.

Primārais gala rezultāts bija procedūras iznākums (sekmīgums) un visu cēloṇu mirstība. HTO tika definēta kā koronārās artērijas pilnīga oklūzija (TIMI plūsma 0), kuras ilgums bija vismaz 3 mēneši. Oklūzijas ilgums tika novērtēts saskan̄ā ar anamnēzi (iepriekš pārciestu miokarda infarktu, pirmo stenokardijas simptomu parādīšanos) vai ņemot vērā iepriekš veiktas angiogrāfijas datus. Ja reǵistrācijas periodā vienu HTO tika mēgināâts atvērt divās vai vairākās 
atsevišķās procedūrās, tikai pēdējā procedūra tika uzskaitīta un iekḷauta analīzē. Ja registrācijas periodā pacientam ar divām vai vairākām HTO PKI mēgināja veikt vairākas reizes un ar atšķirīgu rezultātu (viena procedūra vienai HTO bija veiksmīga, otra procedūra citai $\mathrm{HTO}$ - ne), pacients no registra tika izslēgts. Pētījuma periodā bija 12 šādu pacientu.

Sekmīga procedūra tika definēta kā pilnīga antegrādās asins plūsmas atjaunošana (TIMI plūsmas 3. pakāpe) ar artērijas lūmena atlieku stenozi, ne lielāku par $10 \%$.

\subsection{Sekmīgo un nesekmīgo procedūru salīdzinājums}

No 551 reǵistrēta HTO PKI pacienta 454 gadījumos procedūras bija veiksmīgas. Sekmīgo procedūru skaits 10 gadu laikā pieaudzis no 73,9\% 2007. gadā līdz 84,4 \% 2016. gadā (sk. 2.1. attēlu).

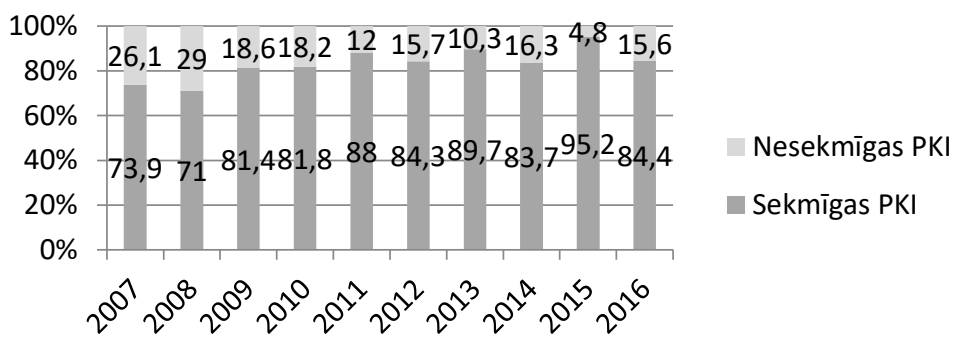

\section{1. attēls. Sekmīgo un nesekmīgo HTO PKI procedūru sadalījums 2007-2016}

Sekmīgu un nesekmīgu gadījumu grupā netika konstatētas būtiskas atšķirības starp sākotnējiem raksturlielumiem (sk. 2.1. tabulu). Nesekmīgo procedūru grupā procentuāli vairāk, taču statistiski nenozīmīgi bija pacienti pēc pārciestiem dokumentētiem miokarda infarktiem un pēc koronāro artēriju šuntēšanas operācijām un statistiski ticami vairāk pacientu pēc iepriekš veiktām PKI. 
HTO PKI pacientu raksturojums

\begin{tabular}{|c|c|c|c|c|}
\hline Rādītājs & $\begin{array}{c}\text { Kopā } \\
(\mathbf{n}=\mathbf{5 5 1})\end{array}$ & $\begin{array}{l}\text { Sekmīgie } \\
\text { gadījumi } \\
(\mathrm{n}=454)\end{array}$ & $\begin{array}{c}\text { Nesekmīgie } \\
\text { gadījumi } \\
(\mathbf{n}=97)\end{array}$ & p-vērtība \\
\hline \begin{tabular}{|l|} 
Vidējais \\
vecums $( \pm \mathrm{SD})$
\end{tabular} & $63,5(10,4)$ & $63,3(10,5)$ & $64,3(9,9)$ & 0,394 \\
\hline Vīrieši, n (\%) & $441(80,0 \%)$ & $364(80,2 \%)$ & $77(79,4 \%)$ & 0,859 \\
\hline $\begin{array}{l}\text { Smēķētāji: } \\
\text { - nekad } \\
\text { - bijušie } \\
\text { - esoši }\end{array}$ & $\begin{array}{c}309(56,1 \%) \\
173(31,4 \%) \\
69(12,5 \%)\end{array}$ & $\begin{array}{c}248(54,6 \%) \\
146(32,2 \%) \\
60(13,2 \%)\end{array}$ & $\begin{array}{c}61(62,9 \%) \\
27(27,8 \%) \\
9(9,3 \%)\end{array}$ & 0,296 \\
\hline Hipertensija & $461(83,7 \%)$ & $383(84,4 \%)$ & $78(80,4 \%)$ & 0,340 \\
\hline Dislipidēmija & $390(70,8 \%)$ & $329(72,5 \%)$ & $61(62,9 \%)$ & 0,060 \\
\hline Diabēts & $110(20,0 \%)$ & $95(20,9 \%)$ & $15(15,5 \%)$ & 0,222 \\
\hline Iepriekš MI & $400(72,6 \%)$ & $323(71,1 \%)$ & $77(79,4 \%)$ & 0,099 \\
\hline Iepriekš KAŠ & $45(8,2 \%)$ & $35(7,7 \%)$ & $10(10,3 \%)$ & 0,396 \\
\hline Iepriekš PKI & $289(52,5 \%)$ & $229(50,4 \%)$ & $60(61,9 \%)$ & 0,041 \\
\hline
\end{tabular}

Salīdzinot anatomiskos rādītājus sekmīgo un nesekmīgo HTO PKI gadījumos, netika konstatēta saistība starp procedūras sekmīgumu un HTO lokalizāciju kreisajā priekšējā lejupejošajā, kreisajā apliecošajā vai labajā koronārajā artērijā. Vidējie okludētās koronārās artērijas diametri abās grupās neatšķīrās. Nesekmīgo procedūru grupā vidējais HTO garums bija lielāks (sk. 2.2. tabulu).

2.2. tabula

Sekmīgās un nesekmīgās HTO PKI. HTO anatomiskais salīdzinājums

\begin{tabular}{|c|c|c|c|c|}
\hline Rādītājs & $\begin{array}{c}\text { Kopā } \\
(\mathbf{n}=\mathbf{5 5 1})\end{array}$ & $\begin{array}{l}\text { Sekmīgie } \\
\text { gadījumi } \\
(\mathrm{n}=\mathbf{4 5 4})\end{array}$ & $\begin{array}{c}\text { Nesekmīgie } \\
\text { gadījumi } \\
\text { (n= 97) }\end{array}$ & p-vērtība \\
\hline $\begin{array}{l}\text { HTO lokalizācija: } \\
\text { - LAD } \\
\text { - LCX } \\
\text { - RCA } \\
\text { - Cita }\end{array}$ & $\begin{array}{c}176(32,0 \%) \\
48(8,7 \%) \\
320(58,0 \%) \\
7(1,3 \%)\end{array}$ & $\begin{array}{c}149(32,7 \%) \\
39(8,5 \%) \\
259(57,1 \%) \\
7(1,7 \%)\end{array}$ & $\begin{array}{c}28(28,9 \%) \\
9(9,3 \%) \\
60(61,9 \%) \\
0(0 \%)\end{array}$ & 0,507 \\
\hline
\end{tabular}


2.2. tabulas turpinājums

\begin{tabular}{|l|c|c|c|c|}
\hline \multicolumn{1}{|c|}{ Rādītājs } & $\begin{array}{c}\text { Kopā } \\
(\mathbf{n}=\mathbf{5 5 1})\end{array}$ & $\begin{array}{c}\text { Sekmīgie } \\
\text { gadījumi } \\
(\mathbf{n = 4 5 4})\end{array}$ & $\begin{array}{c}\text { Nesekmīgie } \\
\text { gadījumi } \\
(\mathbf{n = 9 7})\end{array}$ & p-vērtība \\
\hline $\begin{array}{l}\text { Vidējais HTO } \\
\text { garums ( } \pm \text { SD), mm }\end{array}$ & $22,5(10,1)$ & $22,0(9,8)$ & $24,7(11,0)$ & 0,025 \\
\hline $\begin{array}{l}\text { Vidējais HTO } \\
\text { asinsvada diametrs } \\
( \pm \text { SD), mm }\end{array}$ & $3,2(0,3)$ & $3,2(0,4)$ & $3,3(0,3)$ & 0,172 \\
\hline $\begin{array}{l}\text { Vidējais J-CTO } \\
\text { score }( \pm \text { SD })\end{array}$ & $1,8(1,2)$ & $1,7(1,2)$ & $2,5(1,0)$ & $<0,001$ \\
\hline $\begin{array}{l}\text { Vidējais } \\
\text { PROGRESS score } \\
( \pm \text { SD })\end{array}$ & $0,9(0,8)$ & $0,8(0,8)$ & $1,1(0,7)$ & $<0,001$ \\
\hline $\begin{array}{l}\text { Vidējais CL score } \\
( \pm \text { SD) }\end{array}$ & $3,2(1,4)$ & $3,1(1,4)$ & $3,7(1,3)$ & $<0,001$ \\
\hline $\begin{array}{l}\text { Vidējais CASTLE } \\
\text { score }( \pm \text { SD })\end{array}$ & $1,8(1,0)$ & $1,7(1,0)$ & $2,2(1,0)$ & $<0,001$ \\
\hline
\end{tabular}

Vidējais (mediānais) novērošanas laiks bija 7,5 gadi (IQR 4,6-10,1 gads); minimālais un maksimālais novērošanas laiks - attiecīgi 0,03 gadi un 13,0 gadi. Salīdzinot pacientu izdzīvotību - pacientu skaitu procentuāli, kuri ir dzīvi pēc noteikta laika perioda, statistiski labāka izdzīvotība tika konstatēta sekmīgo procedūru grupā $(p=0,033)$ (sk. 2.2. attēlu).

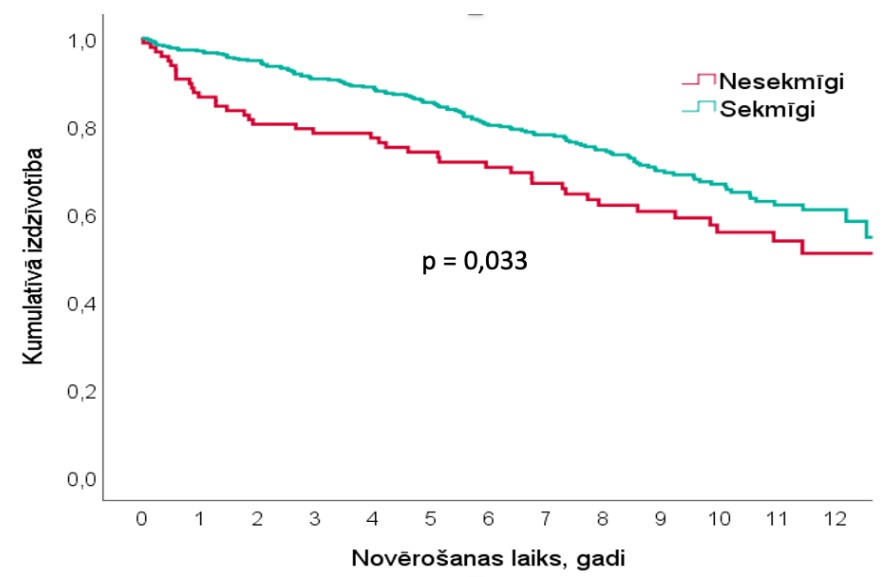

2.2. attēls. Izdzīvotība pēc HTO PKI atkarībā no procedūras rezultāta 
Analizējot mirstības dinamiku pēc 1, 3, 5 un 10 gadiem, lielākais mirstības samazinājums pēc sekmīgām procedūrām tika novērots 3 gadu laikā pēc procedūras, kad sekmīgo PKI grupā bija miruši $9,3 \%$ pacientu, bet nesekmīgo PKI grupā 21,6 \% pacientu (sk. 2.3. tabulu).

2.3. tabula

Izdzīvotība pēc sekmīgām un nesekmīgām HTO PKI.

$1,3,5$ un 10 gadu rezultāti

\begin{tabular}{|l|c|c|c|c|c|}
\hline \multirow{2}{*}{$\begin{array}{c}\text { HTO PKI } \\
\text { rezultāts }\end{array}$} & \multirow{2}{*}{ Mirušie / Visi } & \multicolumn{5}{|c|}{ Izdzīvotība \% (SE) } \\
\cline { 3 - 6 } & & $\mathbf{1 ~ g a d s}$ & $\mathbf{3}$ gadi & $\mathbf{5}$ gadi & 10 gadi \\
\hline Sekmīgs & $128 / 454$ & $97,1(0,8)$ & $90,7(1,4)$ & $85,4(1,7)$ & $66,7(2,7)$ \\
\hline Nesekmīgs & $41 / 97$ & $86,6(3,5)$ & $78,4(4,2)$ & $74,0(4,5)$ & $55,7(5,5)$ \\
\hline
\end{tabular}

\subsection{Izdz̄ivotība pēc sekmīgām un nesekmīgām procedūrām dažādām pacientu grupām}

\subsubsection{Vīrieši un sievietes}

Salīdzinot pacientus pēc dzimuma, statistiski ticama saistība starp sekmīgu procedūru un dzīvildzi konstatēta vīriešiem (long-rank $\mathrm{p}=0,009$ ). Sievietēm turpretim atšķirības starp rezultātiem ilgtermiņā praktiski netika konstatētas (long-rank $\mathrm{p}=0,761) \quad$ (sk. 2.3. attēlu). Iespējamais skaidrojums - nelielais sieviešu kopējais skaits pētījumā -110 . 

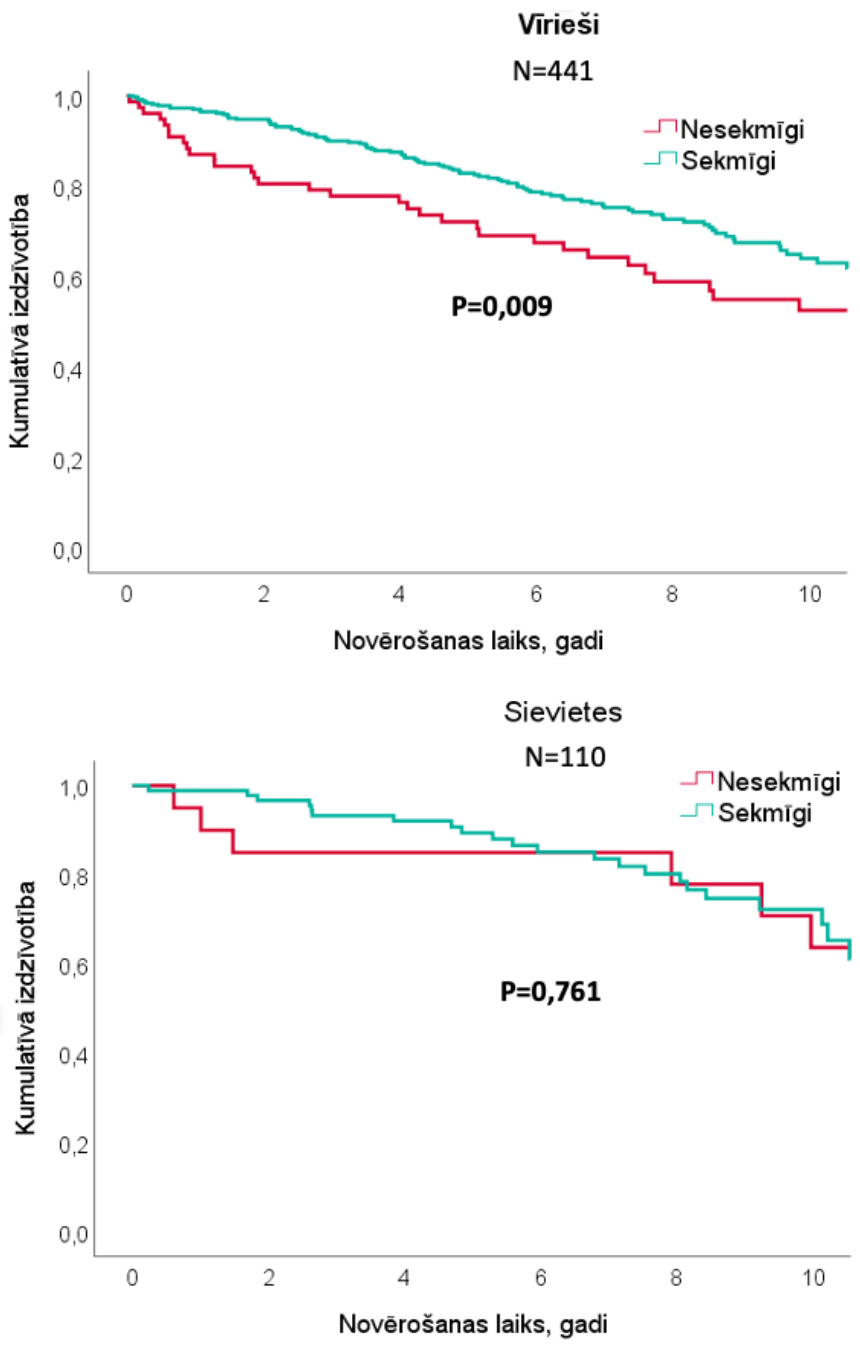

2.3. attēls. HTO PKI sekmīgums / nesekmīgums un dzīvildze vīriešiem un sievietēm 


\subsubsection{Pacienti līdz 65 gadu vecumam un vecāki}

Salīdzinot sekmīgo un nesekmīgo procedūru ilgtermiņa rezultātus pacientiem vecuma grupā līdz 65 gadu vecumam un pēc 65 gadu vecuma, abās vecuma grupās izdzīvotības līkne bija labāka sekmīgu procedūru gadījumā, tomēr šīs atšķirības nevienā vecuma grupā nebija statistiski nozīmīgas (sk. 2.4. attēlu).

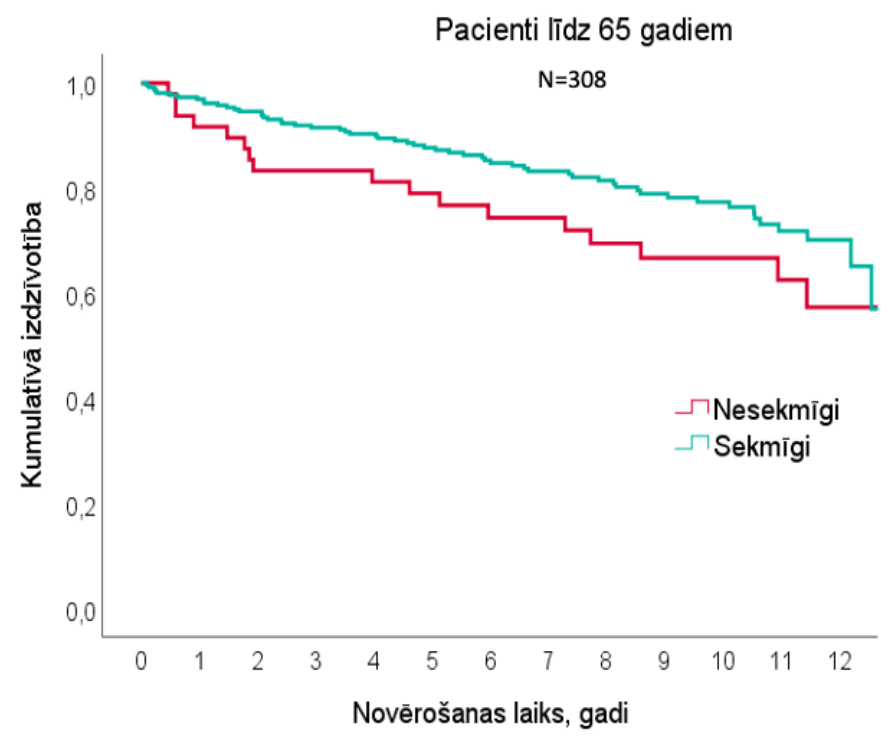




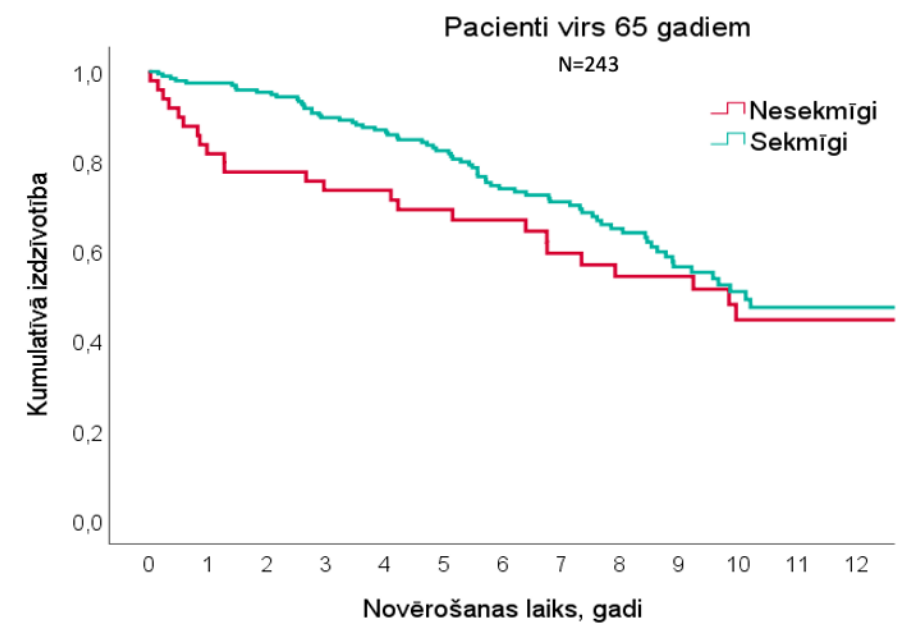

2.4. attēls. HTO PKI sekmīgums / nesekmīgums un izdzīvotība pacientiem līdz 65 gadu vecumam un pēc tā

\subsubsection{Pacienti ar cukura diabētu un pacienti, kuriem tā nav}

Salīdzinot pacientus ar cukura diabētu un pacientus, kuriem tā nav, abās grupās novērota līdzīga procedūras sekmīguma saistība ar dzīvildzi (sk. 2.5. attēlu). 

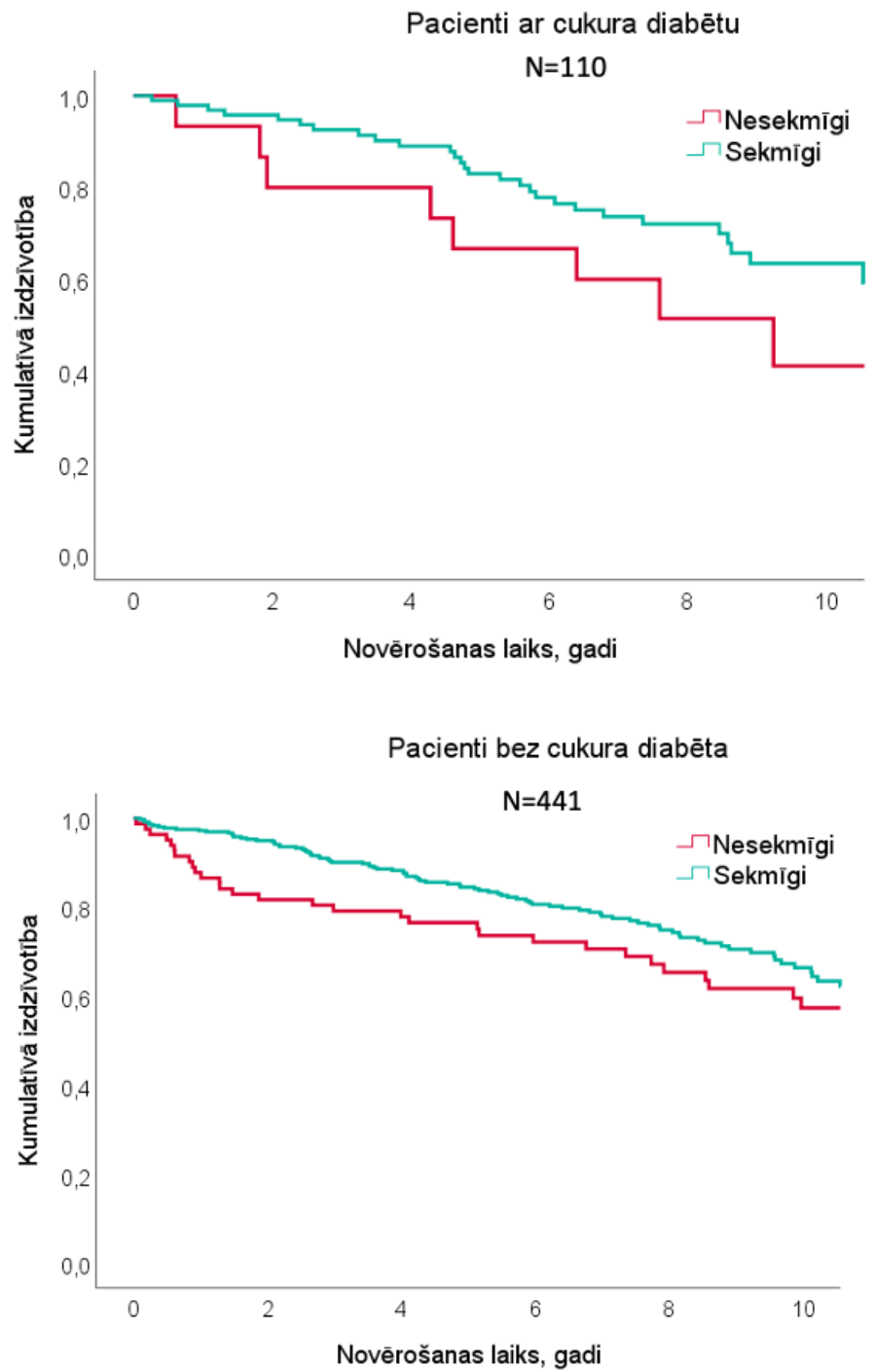

2.5. attēls. HTO PKI rezultāts un izdzīvotība pacientiem ar cukura diabētu un bez tā 
Izmantojot Koksa regresijas metodi un analizējot dzīvildzi atkarībā no procedūras sekmīguma, pacienta vecuma, dzimuma un diabēta esamības vai neesamības, un šos faktorus savstarpēji samērojot, konstatēts, ka mirstība palielinās līdz ar vecumu ( $\mathrm{p}<0,001$, HR 1,05, kas nozīmē, ka nāves risks, vecumam palielinoties par vienu gadu, pieaug par $5 \%$ ), kā arī mirstība bija 1,6 reizes lielāka vīriešiem salīdzinājumā ar sievietēm $(p=0,023)$. Diabēta saistība ar lielāku nāves risku (HR 1,34) nebija statistiski nozīmīga (sk. 2.4. tabulu). Nesekmīgas procedūras gadījumā nāves risks bija par $46 \%$ lielāks, turklāt saistība starp izdzīvotību un procedūras rezultātu pirms un pēc samērošanas bija vienāda. Tātad saistība starp precedūras sekmīgumu un dz̄ivildzi nebija atkarīga no pārējiem modelī iekḷautajiem faktoriem. Nesamērojot pacientus pēc vecuma, mirstība vīriešiem bija par 18 \% lielāka nekā sievietēm, kas nav statistiski ticami, bet, samērojot abus dzimumus pēc vecuma, mirstība vīriešiem bija par 57 \% lielāka.

2.4. tabula

Dzīvildzes saistība ar procedūras rezultātu, pacienta vecumu, dzimumu, cukura diabētu. Koksa regresijas modelis

\begin{tabular}{|c|c|c|c|c|c|c|}
\hline \multirow{2}{*}{ Faktori } & \multicolumn{3}{|c|}{ Bez samērošanas } & \multicolumn{3}{|c|}{$\begin{array}{c}\text { Faktorus savstarpēji } \\
\text { samērojot }\end{array}$} \\
\hline & HR & $95 \% \mathrm{TI}$ & p-vērtība & HR & $95 \% \mathrm{TI}$ & $\begin{array}{c}\text { p- } \\
\text { vērtība }\end{array}$ \\
\hline \multicolumn{7}{|l|}{\begin{tabular}{|l|} 
Vecums: \\
\end{tabular}} \\
\hline $\begin{array}{l}\text { pieaugums par } \\
1 \text { gadu }\end{array}$ & 1,04 & $1,02-1,06$ & $<0,001$ & 1,05 & $1,03-1,06$ & $<0,001$ \\
\hline \multicolumn{7}{|l|}{ Dzimums: } \\
\hline $\begin{array}{l}\text { vīrieši vs. } \\
\text { sievietes }\end{array}$ & 1,18 & $0,81-1,73$ & 0,384 & 1,57 & $1,06-2,32$ & 0,023 \\
\hline \multicolumn{7}{|l|}{ Procedūra: } \\
\hline $\begin{array}{l}\text { nesekmīga vs. } \\
\text { sekmīga }\end{array}$ & 1,47 & $1,03-2,09$ & 0,034 & 1,47 & $1,03-2,09$ & 0,033 \\
\hline \multicolumn{7}{|l|}{ Diabēts: } \\
\hline jā vs. nē & 1,23 & $0,87-1,75$ & 0,248 & 1,34 & $0,94-1,90$ & 0,108 \\
\hline
\end{tabular}




\subsubsection{Pacienti, kam veikta koronāro artēriju šuntēšanas operācija anamnēzēe, un pacienti, kam tās nav bijis}

No visiem reǵistrā iekḷautajiem pacientiem (551) 45 anamnēzē bija veikta koronāro artēriju šuntēšanas operācija. Vidējais pacientu pēc KAŠ vecums bija 64,82 gadi (bez KAŠ grupā 63,35), un 75,56 \% no tiem bija vīrieši. No visām oklūzijām 7 bija lokalizētas LAD, 6 - LCX, 33 - RCA. Sekmīgas bija 77,78 \% procedūru. $50 \%$ gadījumu tika lietota retrogrādā pieeja. Sekmīgo procedūru skaits pacientiem ar KAŠ anamnēzē bija 78,3\%.

Salīdzinot pacientus ar un bez iepriekš veiktas KAŠ operācijas, pacientiem ar KAŠ anamnēzē biežāk bija gan cukura diabēts $(33,3 \%$ pret $18,8 \%, \mathrm{p}=0,019)$, gan pārciests miokarda infarkts $(86,7 \%$ pret $71,3 \%$, $\mathrm{p}=0,027)$. Salīdzinot HTO PKI procedūras tehniskos aspektus un lietotās metodes, pacientiem pēc KAŠ ievērojami biežāk izmantota retrogrādā pieeja (sk. 2.5. tabulu).

Izdzīvotības rādītāji pacientiem ar KAŠ anamnēzē konstatēti sliktāki nekā pacientiem bez KAŠ (sk. 2.6. attēlu, 2.5. un 2.6. tabulu).

2.5. tabula

\section{HTO PKI pacientu ar un bez KAŠ anamnēzē salīdzinājums}

\begin{tabular}{|c|c|c|c|c|}
\hline Rādītājs & $\begin{array}{c}\text { Kopā } \\
(\mathrm{n}=\mathbf{5 5 1}) \\
\end{array}$ & $\begin{array}{c}\text { Pacienti bez KAŠ } \\
(n=506)\end{array}$ & $\begin{array}{c}\text { Pacienti pēc KAŠ } \\
(n=45)\end{array}$ & p-vērtība \\
\hline $\begin{array}{l}\text { Vidējais } \\
\text { vecums } \\
( \pm \mathrm{SN})\end{array}$ & $63,5(10,4)$ & $63,4(10,4)$ & $64,8(10,7)$ & 0,363 \\
\hline Vīrieši, n (\%) & $441(80,0 \%)$ & $407(80,4 \%)$ & $34(75,6 \%)$ & 0,433 \\
\hline $\begin{array}{l}\text { Smēḳētāji: } \\
\text { - nekad } \\
\text { - bijušie } \\
\text { - esoši }\end{array}$ & $\begin{array}{c}309(56,1 \%) \\
173(31,4 \%) \\
69(12,5 \%) \\
\end{array}$ & $\begin{array}{c}286(56,5 \%) \\
158(31,2 \%) \\
62(12,3 \%) \\
\end{array}$ & $\begin{array}{c}23(51,1 \%) \\
15(33,3 \%) \\
7(15,6 \%)\end{array}$ & 0,728 \\
\hline Hipertensija & $461(83,7 \%)$ & $419(82,8 \%)$ & $42(93,3 \%)$ & 0,067 \\
\hline Dislipidēmija & $390(70,8 \%)$ & $354(70,0 \%)$ & $36(80,0 \%)$ & 0,156 \\
\hline Diabēts & $110(20,0 \%)$ & $95(18,8 \%)$ & $15(33,3 \%)$ & 0,019 \\
\hline Iepriekš MI & $400(72,6 \%)$ & $361(71,3 \%)$ & $39(86,7 \%)$ & 0,027 \\
\hline
\end{tabular}


2.5. tabulas turpinājums

\begin{tabular}{|c|c|c|c|c|}
\hline Rādītājs & $\begin{array}{c}\text { Kopā } \\
(\mathrm{n}=\mathbf{5 5 1})\end{array}$ & $\begin{array}{c}\text { Pacienti bez KAS̆ } \\
(n=506)\end{array}$ & $\begin{array}{c}\text { Pacienti pēc KAS̆ } \\
(n=45)\end{array}$ & p-vērtība \\
\hline Iepriekš PKI & $289(52,5 \%)$ & $260(51,4 \%)$ & $29(64,4 \%)$ & 0,093 \\
\hline $\begin{array}{l}\text { Procedūras } \\
\text { sekmīgums }\end{array}$ & $454(82,4 \%)$ & $419(82,8 \%)$ & $35(77,8 \%)$ & 0,396 \\
\hline $\begin{array}{l}\text { Retrogrādās } \\
\text { metodes } \\
\text { lietojums }\end{array}$ & $183(33,2 \%)$ & $160(31,6 \%)$ & $23(51,1 \%)$ & 0,008 \\
\hline
\end{tabular}

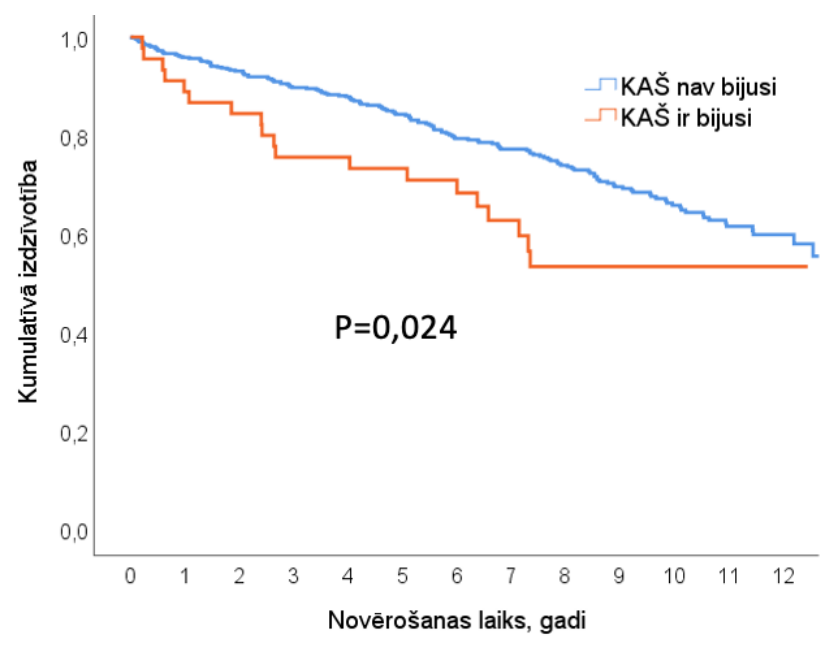

2.6. attēls. Izdzīvotības salīdzinājums HTO PKI pacientiem ar un bez KAŠ anamnēzē

2.6. tabula

\section{Izdz̄ivotība HTO PKI pacientiem ar un bez KAŠ anamnēzē}

\begin{tabular}{|c|c|c|c|c|c|c|}
\hline \multirow{2}{*}{$\begin{array}{c}\text { KA ̌̌ } \\
\text { anamnēzēe }\end{array}$} & \multirow{2}{*}{$\begin{array}{l}\text { Procedūras } \\
\text { rezultāts }\end{array}$} & \multirow{2}{*}{$\begin{array}{l}\text { Mirušie / } \\
\text { Kopā }\end{array}$} & \multicolumn{4}{|c|}{$\begin{array}{c}\text { Izdzīvotība \% (SE) noteiktā laika periodā } \\
\text { pēc procedūras }\end{array}$} \\
\hline & & & 1 gada & 3 gadu & 5 gadu & 10 gadu \\
\hline \multirow{2}{*}{ Ir bijusi } & Sekmīgs & $14 / 35$ & $94,3(3,9)$ & $82,9(6,4)$ & $79,9(6,8)$ & $53,9(9,4)$ \\
\hline & Nesekmīgs & $5 / 10$ & $\begin{array}{c}70,0 \\
(14,5)\end{array}$ & $\begin{array}{c}50,0 \\
(15,8)\end{array}$ & $\begin{array}{c}50,0 \\
(15,8)\end{array}$ & $\begin{array}{c}50,0 \\
(15,8)\end{array}$ \\
\hline
\end{tabular}


2.6. tabulas turpinājums

\begin{tabular}{|c|l|c|c|c|c|c|}
\hline \multirow{2}{*}{$\begin{array}{c}\text { KAŠ } \\
\text { anamnēzē }\end{array}$} & \multirow{2}{*}{$\begin{array}{c}\text { Procedūras } \\
\text { rezultāts }\end{array}$} & \multirow{2}{*}{$\begin{array}{c}\text { Mirušie / } \\
\text { Kopā }\end{array}$} & \multicolumn{4}{|c|}{ Izdzīvotība \% (SE) noteiktā laika periodā } \\
\cline { 4 - 7 } & & \multicolumn{4}{|c|}{ pēc procedūras } \\
\hline \multirow{2}{*}{ Nav bijusi } & Sekmīgs & $114 / 419$ & $97,4(0,8)$ & $91,4(1,4)$ & $85,8(1,7)$ & $68,0(2,8)$ \\
\cline { 4 - 8 } & Nesekmīgs & $36 / 87$ & $88,5(3,4)$ & $81,6(4,2)$ & $76,8(4,6)$ & $56,8(5,8)$ \\
\hline
\end{tabular}

\subsection{Nāves iemesli}

No visiem 169 mirušajiem pacientiem 118 (69,8 \%) gadījumos nāves pamatcēlonis bija sirds un asinsrites sistēmas slimības (I00 - I99 kodi pēc SSK-10), no kuriem 87 gadījumos pamatcēlonis bija koronārā sirds slimība (I20 - I25 kodi pēc SSK-10) un 18 gadījumos - cerebrovaskulāra slimība (I60 - I69 kodi pēc SSK-10). Otra biežākā nāves pamatcēloṇu grupa bija l̦aundabīgi audzēji (C00 - C97 kodi pēc SSK-10), no kā bija miris 31 pacients (18,3\% no mirušajiem).

Analizējot saistību starp procedūras rezultātu un mirstību atkarībā no nāves cēloṇa, nesekmīgo procedūru grupā bija tendence lielākai mirstībai no jebkāda kardiovaskulāra cēloṇa, tomēr atšḳirība nesasniedza statistiskās nozīmības līmeni $(p=0,060)$ (sk. 2.7. attēlu). Salīdzinot nāves no KSS un nāves no ḷaundabīgiem audzējiem, ilgtermiņā statistiski nozīmīgas atšķirības sekmīgo un nesekmīgo procedūru grupās netika konstatētas (sk. 2.8. un 2.9. attēlu). 


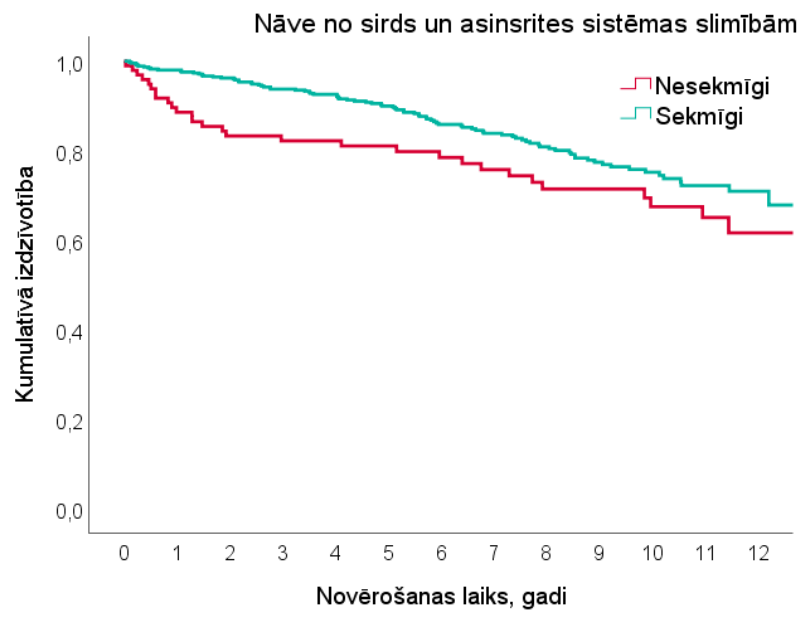

2.7. attēls. Mirstība no jebkāda kardiovaskulāra cēloṇa sekmīgo un nesekmīgo procedūru grupās

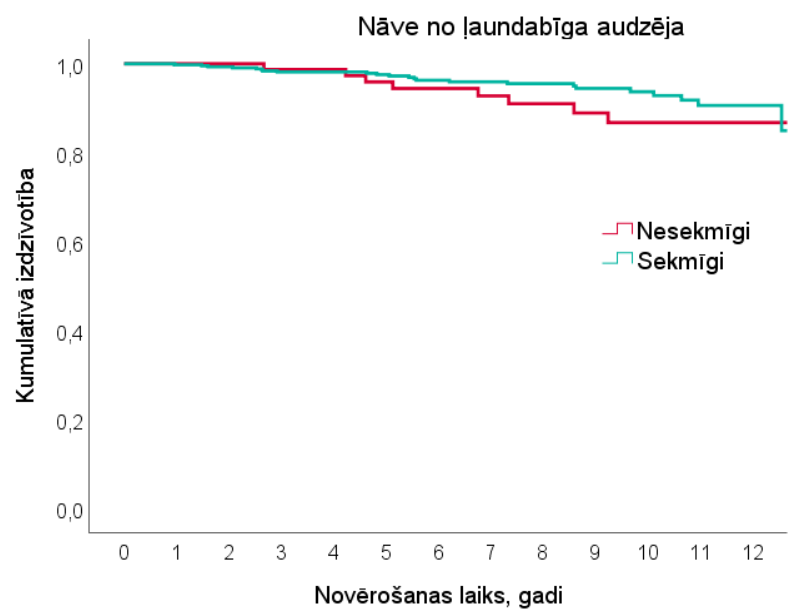

2.8. attēls. Mirstība no ḷaundabīgiem audzējiem sekmīgo un nesekmīgo procedūru grupās 


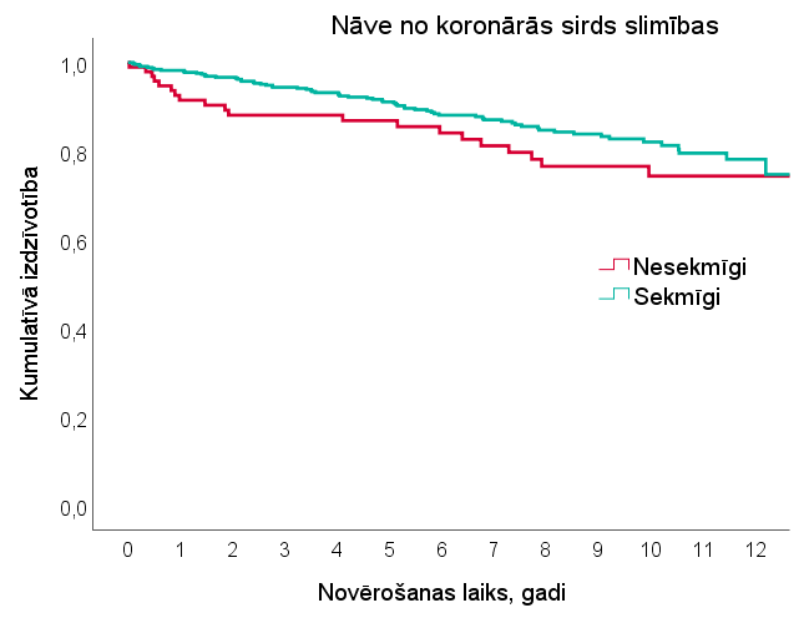

2.9. attēls. Mirstība no KSS sekmīgo un nesekmīgo procedūru grupās

\subsection{Antegrādās un retrogrādās metodes lietošana}

Retrogrādās metodes lietošana pieaugusi no $13 \%$ gadījumu 2007. gadā līdz $51 \%$ gadījumu 2013. gadā un tad atkal samazinājusies līdz 40-46\% 2015.-2016. gadā (sk. 2.10. attēlu). Kopumā no 551 reǵistrā iekḷautā pacienta retrogrādā pieeja lietota 183 (33,39\%) pacientiem (sk. 2.7. tabulu).

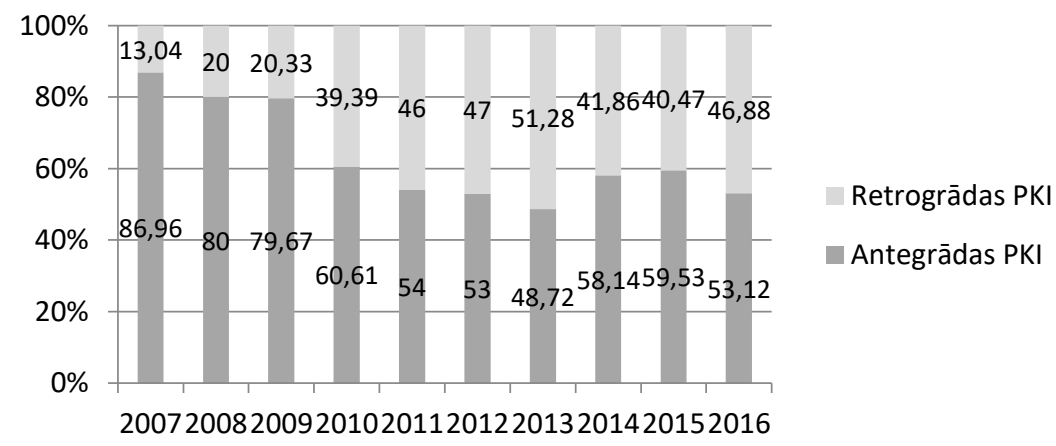

2.10. attēls. Retrogrādās metodes lietojums 2007.-2016. gadā 
Retrogrādo HTO PKI skaits 2007-2016

\begin{tabular}{|l|c|c|c|}
\hline Gads & $\begin{array}{c}\text { Kopā } \\
\text { HTO PKI }\end{array}$ & $\begin{array}{c}\text { Retrogrādas } \\
\text { HTO PKI }\end{array}$ & $\begin{array}{c}\text { Retrogrādo } \\
\text { HTO PKI \% }\end{array}$ \\
\hline 2007 & 69 & 9 & 13,0 \\
\hline 2008 & 100 & 20 & 20,0 \\
\hline 2009 & 59 & 12 & 20,3 \\
\hline 2010 & 65 & 25 & 38,5 \\
\hline 2011 & 50 & 23 & 46,0 \\
\hline 2012 & 51 & 24 & 47,1 \\
\hline 2013 & 34 & 17 & 50,0 \\
\hline 2014 & 42 & 17 & 40,5 \\
\hline 2015 & 42 & 16 & 38,1 \\
\hline 2016 & 39 & 20 & 51,3 \\
\hline Kopā: & 551 & 183 & 33,2 \\
\hline
\end{tabular}

Nav konstatēta biežāka retrogrādās metodes lietošana saistībā ar pacientu vecumu, dzimumu, anamnēzē pārciestu infarktu. Biežāk retrogrādā metode lietota pacientiem pēc KAŠ ( $\mathrm{p}=0,008)$, pēc iepriekš veiktas PKI $(\mathrm{p}<0,001)$, kā arī pacientiem, kuriem HTO mēginājums veikts atkārtoti $(\mathrm{p}=0,003)$. Tāpat biežāk retrogrādā metode izmantota pacientiem ar sarežğîtākiem HTO bojājumiem (ar lielākiem sarežǵîtības rādītājiem, vērtējot pēc visām četrām vērtēšanas skalām) $(\mathrm{p}<0,001)$ (sk. 2.8. tabulu).

No visiem 183 retrogrādo HTO PKI gadījumiem 151 (83\%) gadījumā retrogrādā metode lietota uzreiz pēc nesekmīga mēǵinājuma šḳērsot oklūziju antegrādi un sekmīgas bijušas $92(60,5 \%)$ procedūras. 32 (17 \%) gadījumos procedūra sākta primāri retrogrādi, no tiem 9 gadījumos tas darīts, jo iepriekš jau bijis veikts nesekmīgs antegrāds mēg̣inājums, sekmīgas bijušas attiecīgi $13(59 \%)$ un $5(55 \%)$ procedūras (sk. 2.9. tabulu).

Salīdzinot divas dažādas retrogrādo HTO PKI procedūru veikšanas stratēǵijas - retrogrādās metodes lietošanu uzreiz pēc nesekmīga antegrāda mēg̣inājuma un HTO PKI procedūras, kas uzreiz sāktas ar retrogrādo pieeju, konstatēts, ka primāra retrogrādā pieeja biežāk izvēlēta pacientiem ar sarežg̣ìtāku anatomiju - biežāk HTO bijušas lokalizētas ostiāli un biežāk bijusi neskaidra 
proksimālā ieeja, kā arī tā biežāk lietota, ja iepriekš jau bijis nesekmīgs antegrāds PKI mēǵinājums. Okludētā segmenta garumam primāras vai sekundāras retrogrādas stratēgijas izvēlē nav bijusi nozīme, jo šis rādītājs abās grupās neatšķiras (sk. 2.10. tabulu).

2.8. tabula

\section{Retrogrādās metodes lietošanas korelācija ar dažādiem faktoriem}

\begin{tabular}{|c|c|c|c|c|c|c|c|c|c|c|c|c|c|}
\hline 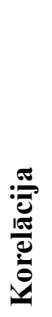 & 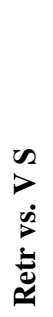 & 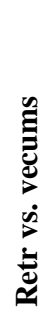 & 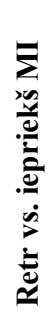 & 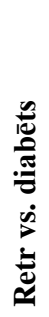 & 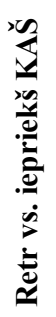 & 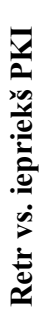 & 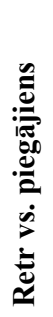 & 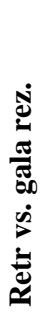 & 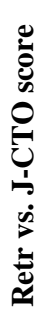 & 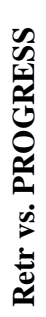 & 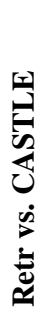 & 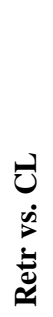 & 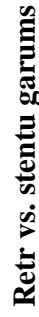 \\
\hline 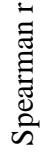 & $\begin{array}{l}\hat{5} \\
0 \\
0 \\
1\end{array}$ & $\frac{a}{0}$ & $\begin{array}{l}\text { ¿े } \\
\text { o. }\end{array}$ & $\begin{array}{l}\overrightarrow{8} \\
0 \\
0\end{array}$ & $\stackrel{m}{=}$ & $\begin{array}{l}\text { त̂ } \\
\text { ֶิ }\end{array}$ & $\begin{array}{l}\hat{\mathrm{N}} \\
\text { Oֵ }\end{array}$ & $\frac{\Omega}{\frac{1}{9}}$ & $\underset{m}{\tilde{m}}$ & $\frac{0}{2}$ & 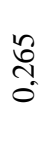 & $\frac{n}{n}$ & $\stackrel{+}{5}$ \\
\hline 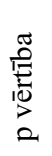 & $\begin{array}{l}0 \\
\stackrel{0}{0} \\
0 \\
0\end{array}$ & $\begin{array}{l}\stackrel{0}{\circ} \\
\stackrel{0}{0}\end{array}$ & $\begin{array}{l}\infty \\
\text { in } \\
0\end{array}$ & $\begin{array}{l}\infty \\
\stackrel{\infty}{0} \\
0\end{array}$ & $\begin{array}{l}\overrightarrow{8} \\
\dot{0} \\
v\end{array}$ & $\begin{array}{l}\overline{8} \\
\dot{0} \\
v\end{array}$ & $\begin{array}{l}\bar{\delta} \\
\delta \\
0 \\
v\end{array}$ & $\begin{array}{l}\overline{8} \\
0 \\
v\end{array}$ & $\begin{array}{l}\overline{8} \\
\dot{0} \\
v\end{array}$ & $\begin{array}{l}\bar{\delta} \\
\dot{0} \\
0 \\
v\end{array}$ & $\begin{array}{l}\overline{8} \\
\dot{0} \\
v\end{array}$ & $\begin{array}{l}\overline{8} \\
8 \\
\dot{0}\end{array}$ & $\begin{array}{l}+ \\
\stackrel{\infty}{0} \\
0\end{array}$ \\
\hline
\end{tabular}

2.9. tabula

Retrogrādās metodes lietošanas stratēğijas un to sekmīgums

\begin{tabular}{|l|c|c|c|}
\hline \multicolumn{1}{|c|}{ Rādītājs } & $\begin{array}{c}\text { Retrogrādā } \\
\text { pieeja uzreiz } \\
\text { pēc nesekmīga } \\
\text { antegrāda } \\
\text { mēginājuma }\end{array}$ & $\begin{array}{c}\text { Procedūra } \\
\text { uzreiz sākta } \\
\text { ar retrogrādo } \\
\text { pieeju }\end{array}$ & $\begin{array}{c}\text { Procedūra sākta } \\
\text { ar retrogrādo pieeju } \\
\text { pēe iepriekš veiktas } \\
\text { nesekmīgas } \\
\text { HTO PKI }\end{array}$ \\
\hline $\begin{array}{l}\text { Kopējais skaits } \\
\text { (sekmīgas / } \\
\text { nesekmīgas) }\end{array}$ & $151(92 / 59)$ & $23(13 / 10)$ & $9(5 / 4)$ \\
\hline $\begin{array}{l}\text { Sekmīgās } \\
\text { procedūras (\%) }\end{array}$ & 61 & 57 & 55 \\
\hline
\end{tabular}


HTO sarežğîtības rādītāji primāras un sekundāras retrogrādās pieejas gadījumos

\begin{tabular}{|l|c|c|}
\hline \multicolumn{1}{|c|}{ Sarežğítības rādītājs } & $\begin{array}{c}\text { Retrogrādā pieeja uzreiz } \\
\text { pēe nesekmīga antegrāda } \\
\text { mēğinājuma (n = 151) }\end{array}$ & $\begin{array}{c}\text { Procedūra uzreiz } \\
\text { sākta ar retrogrādo } \\
\text { pieeju (n = 32) }\end{array}$ \\
\hline $\begin{array}{l}\text { HTO ostiāla } \\
\text { lokalizācija (\%) }\end{array}$ & $16(11 \%)$ & $8(25 \%)$ \\
\hline $\begin{array}{l}\text { Neskaidra proksimālā } \\
\text { ieeja (\%) }\end{array}$ & $41(27 \%)$ & $14(44 \%)$ \\
\hline $\begin{array}{l}\text { Okludētā segmenta garums } \\
>20 m m(\%)\end{array}$ & $80(53 \%)$ & $16(50 \%)$ \\
\hline $\begin{array}{l}\text { Iepriekš veikts nesekmīgs } \\
\text { antegrāds HTO PKI } \\
\text { mēǵinājums (\%) }\end{array}$ & $27(18 \%)$ & $9(28 \%)$ \\
\hline
\end{tabular}

\subsection{Hronisku totālu koronāro artēriju oklūziju sarežğītības, kas novērtēta pēc dažādām skalām, saistība ar PKI rezultātiem}

Visiem pētījumā iekḷautajiem pacientiem (551) retrospektīvi tika aprēḳināti HTO sarežğîtības rādītāji pēc 4 dažādām novērtēšanas sistēmām: J-CTO, PROGRESS, CASLTE un CL score. Atkarībā no savākto punktu skaita pacienti tika sadalīiti grupās pēc HTO sarežğîtības pakāpes. Pacientu sadalījums bija nevienmērīgs, lielākā daḷa pacientu iekḷāvās zemas un vidējas sarežğîtīibas pakāpes grupās (sk. 2.11. tabulu). 
Pacientu sadalījums pēc HTO sarežğīitības, kas noteikta pēc dažādām novērtējumu sistēmām

\begin{tabular}{|c|c|c|c|c|c|c|c|}
\hline \multicolumn{2}{|c|}{ J-CTO } & \multicolumn{2}{|c|}{ PROGRESS } & \multicolumn{2}{|c|}{ CASTLE } & \multicolumn{2}{|c|}{ CL* } \\
\hline Punkti & $\mathbf{N}$ & Punkti & $\mathbf{N}$ & Punkti & $\mathbf{N}$ & Punkti & $\mathbf{N}$ \\
\hline 0 & 82 & 0 & 182 & 0 & 62 & \multirow{6}{*}{$\begin{array}{c}0-1 \\
1,5-2,5 \\
>2,5\end{array}$} & \multirow{6}{*}{$\begin{array}{c}71 \\
146 \\
334\end{array}$} \\
\hline 1 & 165 & 1 & 255 & 1 & 146 & & \\
\hline 2 & 165 & 2 & 105 & 2 & 202 & & \\
\hline 3 & 111 & 3 & 9 & 3 & 118 & & \\
\hline 4 & 28 & 4 & 0 & 4 & 22 & & \\
\hline 5 & 0 & - & - & 5 un 6 & 1 & & \\
\hline
\end{tabular}

* Sarežḡîtās punktu uzskaites dēl CL skalā iespējami 16 dažādi rezultāti, tāpēc pacienti sadalīti trijās grupās.

Salīdzinot HTO sarežğîtības novērtējumus ar procedūru rezultātiem, tika konstatēts, ka, palielinoties sarežḡîtības pakāpei, sekmīgo procedūru skaits ievērojami samazinājās visās vērtēšanas sistēmās (sk. 2.11. attēlu), bet PROGRESS CTO rādītājā tas bija mazāk nozīmīgs (sk. 2.12. un 2.13. tabulu). Visām četrām vērtēšanas sistēmām bija mērena prognozēšanas spēja (AUC J- CTO vērtībai 0,714, p <0,001; AUC PROGRESS CTO vērtībai 0,605, $\mathrm{p}<0,001$; AUC CL vērtībai 0,624, $\mathrm{p}<0,001$; AUC CASTLE vērtībai 0,641, $\mathrm{p}<0,001)$. Tomēr J-CTO rezultāts bija precīzāks par citiem rādītājiem (sk. 2.11. attēlu).

2.12. tabula

Pacientu sadalījums pēc HTO sarežg̀îtības pakāpes un tā korelācija ar procedūras rezultātu

\begin{tabular}{|c|c|c|c|}
\hline $\begin{array}{l}\text { Slimības sarežğītība } \\
\text { (score } \text { novērtējumi) }\end{array}$ & Skaits & $\begin{array}{c}\text { Sekmīgās } \\
\text { procedūras, n (\%) }\end{array}$ & p-vērtība \\
\hline \multicolumn{4}{|l|}{ J-CTO } \\
\hline Zems $(0 ; 1)$ & 247 & $229(92,7 \%)$ & \multirow{3}{*}{$<0,001$} \\
\hline Vidējs (2) & 165 & $136(82,4 \%)$ & \\
\hline Augsts $(3 ; 4 ; 5)$ & 139 & $89(64,0 \%)$ & \\
\hline
\end{tabular}


2.12. tabulas turpinājums

\begin{tabular}{|c|c|c|c|}
\hline $\begin{array}{l}\text { Slimības sarežğītība } \\
\text { (score novērtējumi) }\end{array}$ & Skaits & $\begin{array}{c}\text { Sekmīgās } \\
\text { procedūras, n (\%) }\end{array}$ & p-vērtība \\
\hline \multicolumn{4}{|l|}{ PROGRESS } \\
\hline Zems $(0 ; 1)$ & 437 & $369(84,4 \%)$ & \multirow{2}{*}{0,014} \\
\hline Augsts $(2 ; 3 ; 4)$ & 114 & $85(74,6 \%)$ & \\
\hline \multicolumn{4}{|l|}{ CASTLE } \\
\hline Zems $(0 ; 1)$ & 208 & $188(90,4 \%)$ & \multirow{3}{*}{$<0,001$} \\
\hline Vidējs $(2 ; 3)$ & 320 & $250(78,1 \%)$ & \\
\hline Augsts (4-6) & 23 & $16(69,6 \%)$ & \\
\hline \multicolumn{4}{|l|}{$\mathbf{C L}$} \\
\hline Zems (0-1) & 71 & $68(95,8 \%)$ & \multirow{3}{*}{$<0,001$} \\
\hline Vidējs $(1,5-2,5)$ & 146 & $126(86,3 \%)$ & \\
\hline Augsts (> 2,5) & 334 & $260(77,8 \%)$ & \\
\hline
\end{tabular}

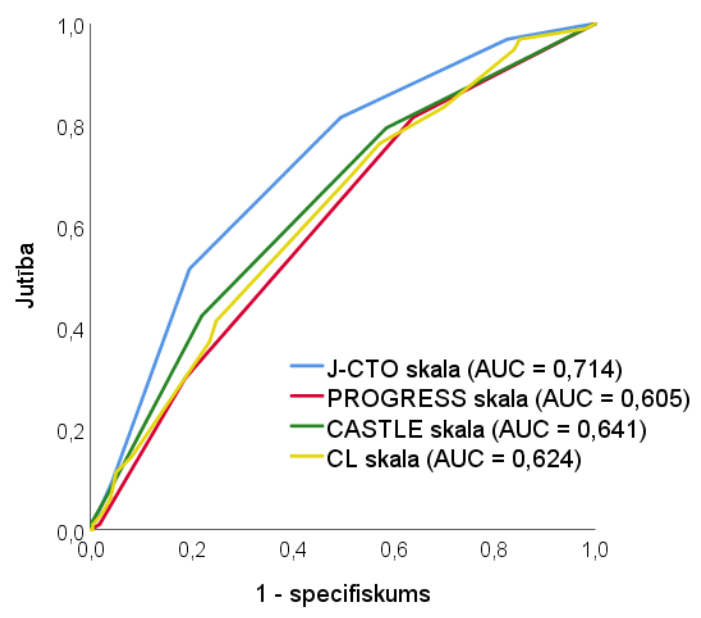

2.11. attēls. ROC līknes: sekmīgas procedūras prognozējamība pēc dažādām HTO sarežğîtīibas vērtēšanas skalām 
ROC līknes: sekmīgas procedūras prognozējamība pēc dažādām HTO sarežǵītības vērtēšanas skalām

\begin{tabular}{|l|c|c|c|}
\hline $\begin{array}{c}\text { Novērtēšanas } \\
\text { sistēma }\end{array}$ & AUC* & $\mathbf{9 5} \%$ TI & p-vērtība \\
\hline J-CTO & 0,714 & $0,660-0,768$ & $<0,001$ \\
\hline PROGRESS & 0,605 & $0,546-0,665$ & 0,001 \\
\hline CASTLE & 0,641 & $0,581-0,701$ & $<0,001$ \\
\hline CL & 0,624 & $0,565-0,683$ & $<0,001$ \\
\hline
\end{tabular}

*AUC - laukums zem līknes.

HTO sarežğīitība, kas novērtēta pēc PROGRESS un CASTLE rādītājiem, parādīja saistību ar visu iemeslu mirstību (sk. 2.12. attēlu), tomēr pēc pieciem gadiem novērojumu saistība tika konstatēta tikai PROGRESS rādītāja gadījumā (sk. 2.14. tabulu). Pacientiem ar augstu PROGRESS rādītāju mirstība bija par $64 \%$ augstāka nekā pacientiem ar zemu punktu skaitu (HR 1,64; $95 \%$ TI 1,09-2,46); tiem, kuriem bija augsts un vidējs CASTLE rādītājs, mirstība bija attiecīgi 2,6 reizes (HR 2,64; $95 \%$ TI 1,1-6,27) un divas reizes (HR 2,05; $95 \%$ TI 1,39-3,02) augstāka nekā pacientiem ar zemu rezultātu. Samērošana pēc dzimuma un J-CTO un PROGRESS rādītāju gadījumā arī pēc vecuma (jo vecums šajos rādītājos nav iekḷauts) neietekmēja rezultātus (sk. 2.15. tabulu).

Turpmāka CASTLE rādītāja salīdzināšana ar vecumu nedaudz samazināja asociācijas stiprumu: mirstības HR pacientiem ar augstu rezultātu bija 1,83 (95 \% TI 0,75-4,50; p =0,185) un pacientiem ar vidēju riska rādītāju 1,63 (95 \% TI 1,09-2,45; p = 0,017) salīdzinājumā ar grupu ar viszemāko punktu skaitu, kas liecina, ka lielāks vecums daḷēji veicināja šo saistību. PROGRESS rādītāja gadījumā vecuma korekcija neietekmēja aprēḳinus. 

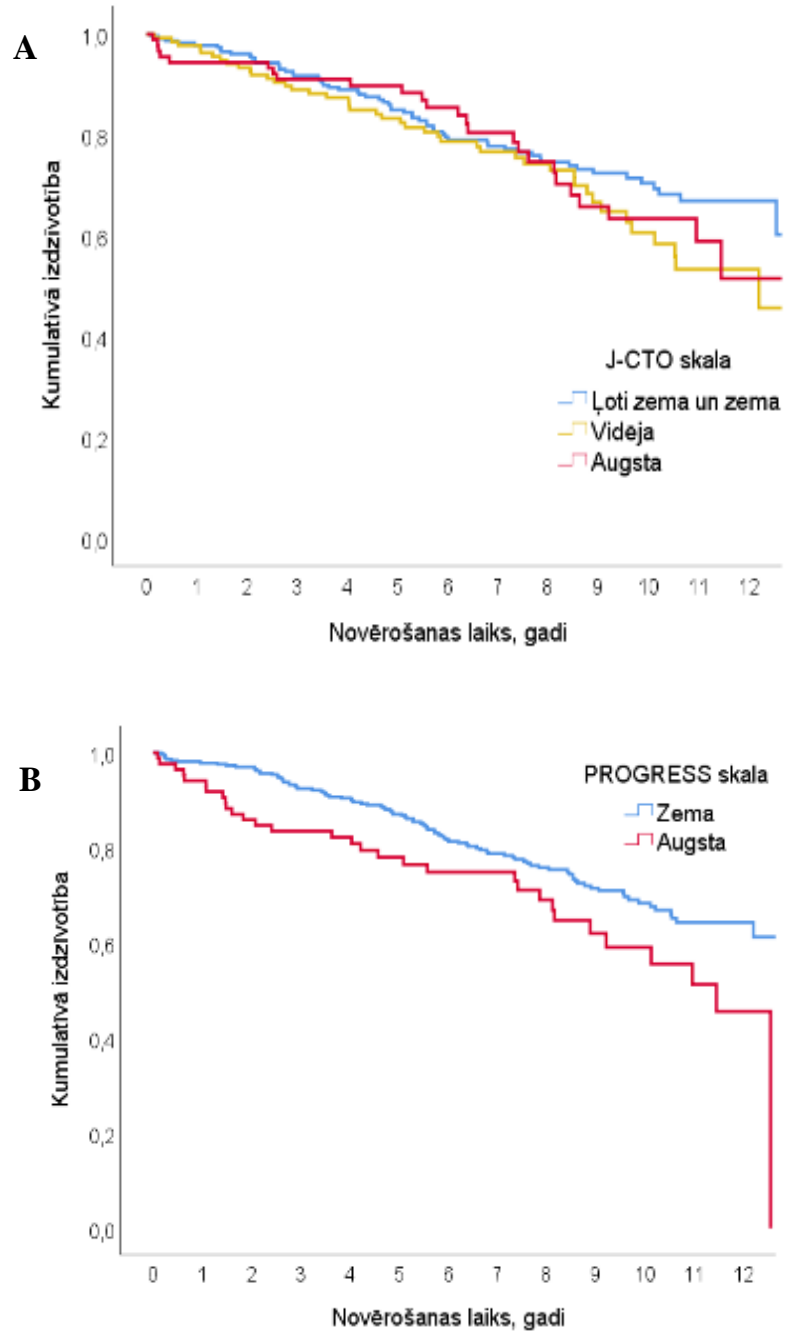

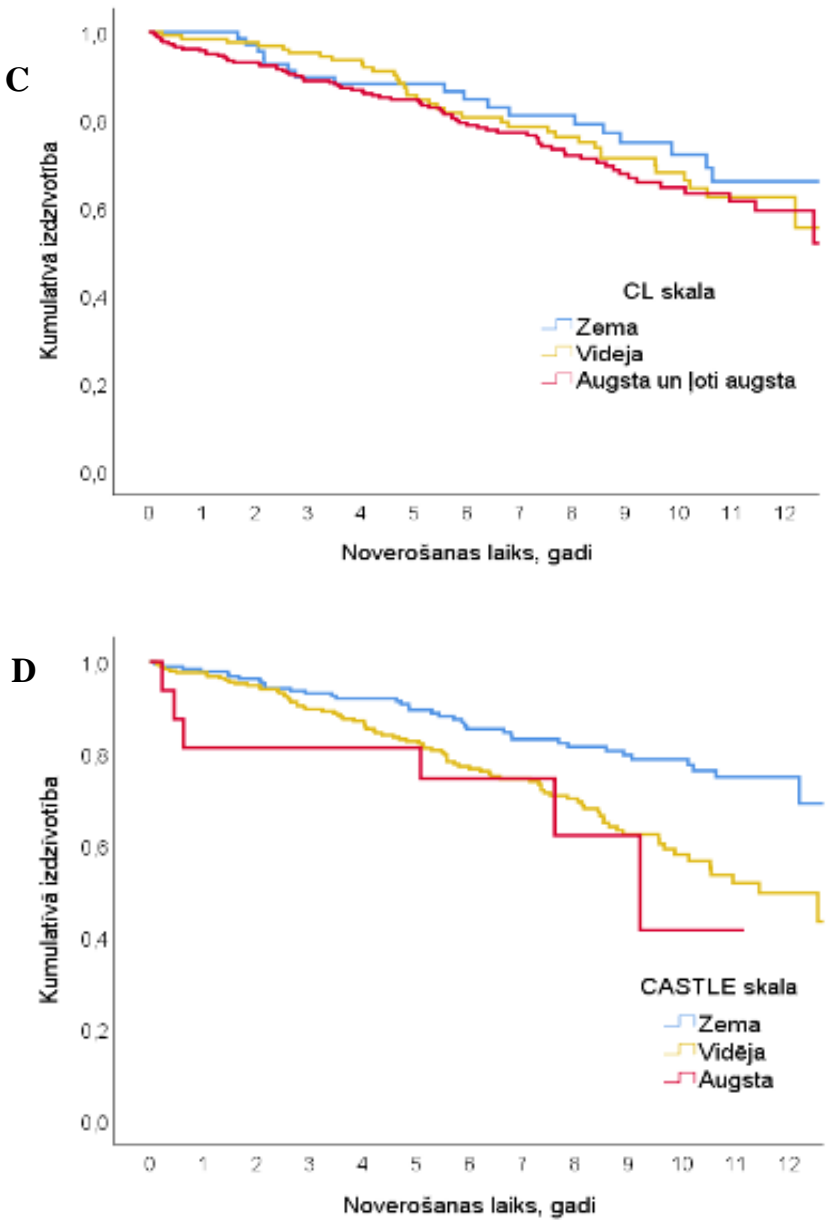

2.12. attēls. HTO pacientu dzīvildze pēc veiksmīgas procedūras atkarībā no sarežğîtības pakāpes, kas novērtēta ar dažādām vērtēšanas sistēmām

A - J-CTO skala; B - PROGRESS skala; C - CL skala; D - CASTLE skala. 
Saistība starp HTO sarežğītību un 5 gadu dzīvildzi pēc dažādām vērtēšanas sistēmām pacientiem pēc sekmīgām PKI procedūrām

\begin{tabular}{|c|c|c|c|}
\hline $\begin{array}{c}\text { HTO sarežğîtība } \\
\text { (score } \text { novērtējums) }\end{array}$ & $\begin{array}{c}5 \text { gadu } \\
\text { dzivildze, \% }\end{array}$ & $95 \%$ TI, \% & $\begin{array}{c}\text { p- } \\
\text { vêrtība }\end{array}$ \\
\hline \multicolumn{4}{|l|}{ J-CTO } \\
\hline Zems $(0 ; 1)$ & 83,5 & $78,4-88,6$ & \multirow{3}{*}{$>0,05$} \\
\hline Vidējs (2) & 81,9 & $75,2-88,6$ & \\
\hline Augsts $(3 ; 4 ; 5)$ & 89,5 & $83,0-96,0$ & \\
\hline \multicolumn{4}{|l|}{ PROGRESS } \\
\hline Zems $(0 ; 1)$ & 86,3 & $82,6-90,0$ & \multirow{2}{*}{0,028} \\
\hline Augsts $(2 ; 3 ; 4)$ & 74,6 & $64,8-84,4$ & \\
\hline \multicolumn{4}{|l|}{ CASTLE } \\
\hline Zems $(0 ; 1)$ & 88,0 & $83,1-92,9$ & \multirow{3}{*}{$>0,05$} \\
\hline Vidējs $(2 ; 3)$ & 81,9 & $77,0-86,8$ & \\
\hline Augsts $(4 ; 5 ; 6)$ & 74,5 & $52,9-96,1$ & \\
\hline \multicolumn{4}{|l|}{ CL } \\
\hline Zems $(0-1)$ & 86,3 & $78,1-94,5$ & \multirow{3}{*}{$>0,05$} \\
\hline Vidējs $(1,5-2,5)$ & 84,0 & $77,1-90,9$ & \\
\hline Augsts $(\geq 2,5)$ & 83,7 & $79,0-88,4$ & \\
\hline
\end{tabular}

2.15. tabula

Saistība starp HTO sarežğìtīibu un dzīvildzi visā novērošanas periodā pacientiem pēc sekmīgām HTO PKI procedūrām

\begin{tabular}{|c|c|c|c|c|c|c|c|}
\hline \multirow{2}{*}{$\begin{array}{c}\text { Novērtēšanas } \\
\text { sistēma, } \\
\text { sarežğìtības } \\
\text { novērtējums }\end{array}$} & \multirow{2}{*}{$\underset{\text { kopā }}{\text { Mirušie / }}$} & \multicolumn{3}{|c|}{ Bez samērošanas } & \multicolumn{3}{|c|}{$\begin{array}{c}\text { Samērots pēc dzimuma } \\
\text { un vecuma* }\end{array}$} \\
\hline & & HR & $95 \%$ TI & \begin{tabular}{c|}
$p-$ \\
vērtība
\end{tabular} & HR & $95 \%$ TI & $\begin{array}{c}\text { p- } \\
\text { vērtība }\end{array}$ \\
\hline \multicolumn{8}{|l|}{ J-CTO } \\
\hline Zems $(0-1)$ & $60 / 229$ & Ref. & - & - & Ref. & - & - \\
\hline Vidējs (2) & $43 / 136$ & 1,33 & $0,90-1,97$ & 0,151 & 1,34 & $0,91-1,99$ & 0,142 \\
\hline Augsts (3-5) & $25 / 89$ & 1,18 & $0,74-1,88$ & 0,490 & 1,12 & $0,70-1,79$ & 0,641 \\
\hline \multicolumn{8}{|l|}{ PROGRESS } \\
\hline Zems $(0-1)$ & $97 / 369$ & Ref. & $\begin{array}{llll}- & & & \end{array}$ & - & Ref. & $\begin{array}{lll}- & \\
\end{array}$ & $\begin{array}{llll}- & \\
\end{array}$ \\
\hline Augsts (2-4) & $31 / 85$ & 1,64 & $1,09-2,46$ & 0,017 & 1,69 & $1,12-2,55$ & 0,012 \\
\hline \multicolumn{8}{|l|}{ CASTLE } \\
\hline Zems (0-1) & $37 / 188$ & Ref. & - & - & Ref. & - & - \\
\hline Vidējs $(2-3)$ & $85 / 250$ & 2,05 & $1,39-3,02$ & $<0,001$ & 2,05 & $1,39-3,03$ & $<0,001$ \\
\hline Augsts (4-6) & $6 / 16$ & 2,64 & $1,11-6,27$ & 0,028 & 2,66 & $1,12-6,33$ & 0,027 \\
\hline
\end{tabular}


2.15. tabulas turpinājums

\begin{tabular}{|c|c|c|c|c|c|c|c|}
\hline \multirow{2}{*}{$\begin{array}{c}\text { Novērtēšanas } \\
\text { sistēma, } \\
\text { sarežğīīības } \\
\text { novērtējums }\end{array}$} & \multirow{2}{*}{$\begin{array}{c}\text { Mirušie / } \\
\text { kopā }\end{array}$} & \multicolumn{3}{|c|}{ Bez samērošanas } & \multicolumn{3}{|c|}{$\begin{array}{c}\text { Samērots pēc dzimuma } \\
\text { un vecuma* }\end{array}$} \\
\hline & & HR & 9 & $\begin{array}{c}\text { p- } \\
\text { vērtîba }\end{array}$ & HR & $95 \%$ TI & $\begin{array}{c}\text { p- } \\
\text { vērtība }\end{array}$ \\
\hline \multicolumn{8}{|l|}{$\mathbf{C L}$} \\
\hline$\overline{\mathrm{Zem}}$ & & & 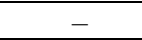 & & 1. & - & - \\
\hline $\begin{array}{l}\text { Vidējs } \\
(1,5-2,5) \\
\end{array}$ & 5 & 1,16 & 0,66 & 0 & 1,16 & $0,66-2,05$ & 0,605 \\
\hline Augsts $(>2,5)$ & $74 / 260$ & 1,33 & $0,80-2,24$ & 0,275 & 1,33 & $0,79-2,24$ & 0,281 \\
\hline
\end{tabular}

* CASTLE un CL - tikai samērots pēc dzimuma, jo vecums jau ir iekḷauts skalā.

\subsection{Komplikācijas}

Nopietnas, ar vaskulārās pieejas vietu saistītas komplikācijas netika konstatētas nevienam no pētījumā iekḷautajiem pacientiem. Tāpat nevienam no pacientiem netika konstatētas ar kontrasta ievadīšanu un ar radiāciju saistītas komplikācijas. Nieru funkcijas rādītāji pēc procedūrām tika kontrolēti vien̄̄gi pacientiem ar zināmiem nieru darbības traucējumiem.

Kardiālas, ar PKI procedūru saistītas komplikācijas novērotas 29 pacientiem, kas veido 5,25\%. Reǵistrētas divas aortālas disekcijas, kas abas ārstētas konservatīvi. Trijos gadījumos konstatēta materiālu iestrēgšana. 19 gadījumos notikušas koronāro artēriju perforācijas, kas 5 gadījumos novedušas pie sirds tamponādes. Visi tamponādes gadījumi sekmīgi ārstēti ar perikarda drenāžu un sekojošu koilu ievietošanu perforētajā asinsvadā. Nāves gadījumi intrahospitālajā etapā nevienam no pacientiem nav konstatēti.

Procentuāli vairāk perforāciju konstatēts pacientiem, kuriem lietota retrogrādā pieeja (perforācijas 5,46 \% pret 2,44 \%) (sk. 2.16. tabulu).

Salīdzinot kumulatīvo izdzìvotību pacientiem pēc sekmīgām HTO PKI procedūrām, nav konstatēta nozīmīga atšķirība starp pacientiem, kuriem lietota tikai antegrādā pieeja, un tiem, kuriem izmantota retrogrādā metode. Arī salīdzinot kumulatīvo izdzīvotību pacientiem pēc nesekmīgām HTO PKI, nav 
konstatēta atšḳirība atkarībā no antegrādās vai retrogrādās pieejas, kas liecina, ka lielākais perforāciju skaits retrogrādās metodes grupā pacientu ilgtermiṇa izdzīvotību neietekmē (sk. 2.13. un 2.14. attēlu).

2.16. tabula

HTO PKI komplikācijas

\begin{tabular}{|l|c|c|c|c|}
\hline \multicolumn{1}{|c|}{ Komplikācijas } & $\begin{array}{c}\text { Kopā } \\
(\mathbf{n = 5 5 1 )}\end{array}$ & $\begin{array}{c}\text { Antegrāda } \\
\text { pieeja } \\
(\mathbf{n = 3 6 8 )}\end{array}$ & $\begin{array}{c}\text { Retrogrāda } \\
\text { pieeja } \\
(\mathbf{n = 1 8 3})\end{array}$ & $\begin{array}{c}\text { p- } \\
\text { vērtība }\end{array}$ \\
\hline Aortas disekcija & $2(0,36 \%)$ & $1(0,27 \%)$ & $1(0,54 \%)$ & - \\
\hline $\begin{array}{l}\text { Materiālu iestrēgšana, } \\
\text { "pazaudēšana" }\end{array}$ & $3(0,54 \%)$ & $2(0,54 \%)$ & $1(0,54 \%)$ & - \\
\hline $\begin{array}{l}\text { Perforācija, t. sk. sirds } \\
\text { tamponāde }\end{array}$ & $\begin{array}{c}19(3,44 \%) \\
5(0,90 \%)\end{array}$ & $\begin{array}{l}9(2,44 \%) \\
1(0,27 \%)\end{array}$ & $\begin{array}{c}10(5,46 \%) \\
4(2,18 \%)\end{array}$ & $\begin{array}{c}\mathrm{p}=0,07 \\
\mathrm{p}=0,03\end{array}$ \\
\hline $\begin{array}{l}\text { Nāve intrahospitālajā } \\
\text { periodā }\end{array}$ & 0 & 0 & 0 & - \\
\hline
\end{tabular}

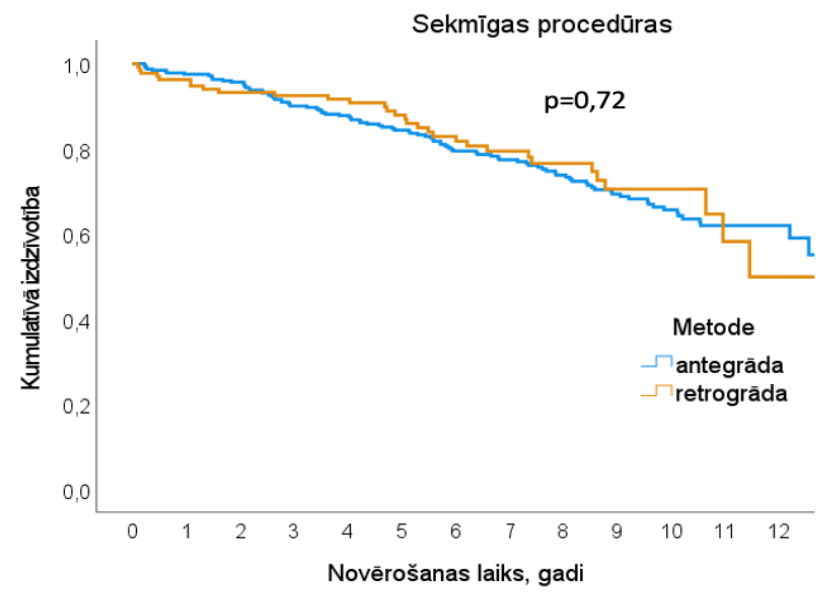

2.13. attēls. Kumulatīvās izdzīvotības salīdzinājums pēc sekmīgām HTO PKI procedūrām, kas veiktas ar retrogrādo vai tikai antegrādo metodi 


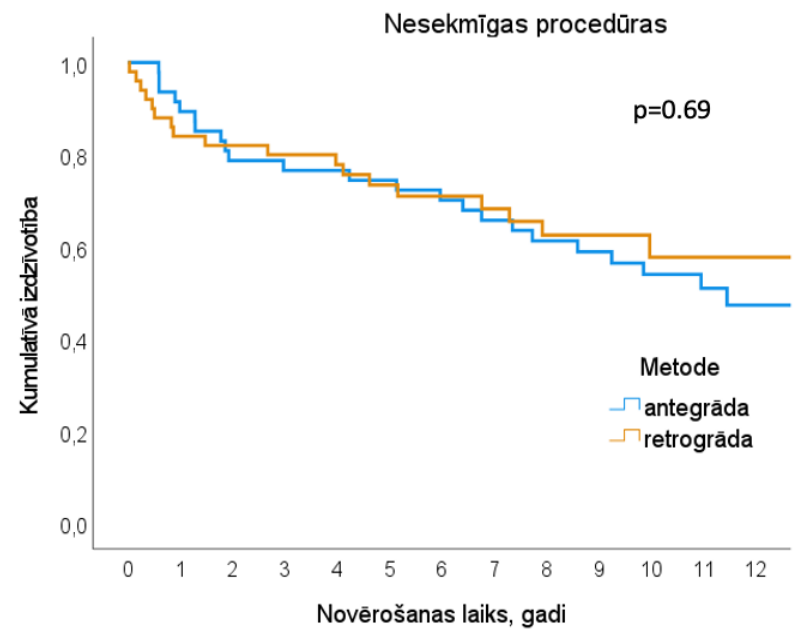

2.14. attēls. Kumulatīvās izdzīvotības salīdzinājums pēc nesekmīgām HTO PKI procedūrām, kas veiktas ar retrogrādo vai tikai antegrādo metodi 


\section{Diskusija}

Šajā retrospektīvajā pētījumā analizēta 551 pacienta grupa, kam 10 gadu laikā tika veiktas HTO PKI procedūras vienā centrā. 454 procedūras bija veiksmīgas. Sekmīgo procedūru skaits pieaudzis no 73,9 \% 2007. gadā līdz 84,4 \% 2016. gadā. Sekmīgo procedūru pieaugums korelē ar retrogrādās pieejas izmantošanas pieaugumu, kas palielinājusies no 13,04\% 2007. gadā līdz 46,88 \% 2016. gadā. 2014. gadā publicētajā 26 pētījumu metaanalīzē par retrogrādās metodes izmantošanu novērotas līdzīgas tendences (El Sabbagh, 2014).

Pētījums apstiprināja, ka pacientiem pēc veiksmīgas HTO PKI bija labāka izdzīvotība salīdzinājumā ar nesekmīgu HTO PKI grupu. Vairāki nejauši salīdzinoši pētījumi ir parādījuši HTO rekanalizācijas labvēlīgo ietekmi uz simptomiem, dzīves kvalitāti un kreisā kambara funkciju (Christakopoulos et al., 2015; Joyal et al, 2010), savukārt tā ietekme uz ilgtermiṇa prognozi joprojām nav skaidra (Christakopoulos et al., 2015; Joyal et al., 2010; Lee et al., 2016; Henriques et al., 2016). Tā, piemēram, iepriekš veiktajā DECISION-CTO pētījumā visu veidu izraisītās nāves, MI, insulta un jebkādas revaskularizācijas trīs gadu periodā bija līdzīgas PKI un optimālas medikamentozas terapijas un tikai optimālas medikamentozas terapijas grupām (20,6 \% pret 19,6 \%) (Lee, 2019). Jāpiebilst gan, ka tikai medikamentozas terapijas grupa šajā pētījumā bija visai nosacīta, jo šīs grupas pacientiem tika piẹ̦auts veikt perkutānās koronārās intervences ne HTO bojājumiem un vidējais stentu skaits, kas tika implantēts vienam optimālas medikamentozas terapijas grupas pacientam, būtiski neatškīīās no PKI grupas pacienta stentu skaita.

Plašas diskusijas nesen izraisīja ISCHEMIA pētījums. Lai gan ISCHEMIA nebija HTO pētījums, tajā tika iekḷauti pacienti ar pierādītu išēmiju, un arī šajā pētījumā neizdevās pierādīt, ka revaskularizācija papildus optimālai medikamentozai terapijai sniedz klīnisku ieguvumu. 
HTO PKI efektivitāte simptomu mazināšanai ir apstiprināta Euro CTO pētījumā, kas parādīja labāku PKI un optimālas medikamentozas terapijas ietekmi uz stenokardijas biežumu un dzīves kvalitāti, salīdzinot ar tikai optimālu medikamentozu terapiju bez PKI (Werner et al., 2018), tāpēc HTO PKI mūsdienās pamatā tiek veiktas simptomātiskiem pacientiem un atteikums no HTO PKI bieži tiek pamatots ar randomizētu datu trūkumu, ka veiksmīga HTO PKI varētu uzlabot ilgterminina rezultātu.

Kawashima, analizējot Syntax pētījumā iekḷautos 460 pacientus ar vismaz vienu HTO un salīdzinot 10 gadu rezultātus pacientiem pēc sekmīgām un pacientiem pēc nesekmīgām HTO revaskularizācijām, nekonstatēja atškirīības mirstībā, turklāt neatkarīgi no tā, vai pacientam bija veikta PKI vai KAŠ (sk. 3.1. tabulu) (Kawashima et al., 2021).

3.1. tabula

10 gadu mirstība HTO pacientiem pēc invazīvas rekanalizācijas un ķirurğiski veiktas revaskularizācijas (Kawashima, 2021)

\begin{tabular}{|l|c|c|c|c|}
\cline { 2 - 5 } \multicolumn{1}{c|}{} & Sekmīgas & Nesekmīgas & HR & 95 \% TI \\
\hline PKI & $29,9 \%$ & $29,4 \%$ & 0,99 & $0,47-2,08$ \\
\hline KA ̌ & $28,0 \%$ & $21,4 \%$ & 0,66 & $0,28-1,53$ \\
\hline
\end{tabular}

Šajā pētījumā arī netika konstatēts, ka HTO lokalizācija ietekmētu mirstību. Salīdzinot HTO tikai kreisajā priekšējā lejupejošajā un HTO kreisajā apliecošajā artērijā, mirstība, salīdzinot sekmīgi un nesekmīgi rekanalizētos vai revaskularizētos pacientus, neatškīīās (34,5 \% pret 26,9 \%; koriǵētā HR 0,90; $95 \%$ TI 0,31-2,56). Salīdzinot PKI un KAŠ, PKI sekmīguma rādītāji bija zemāki, nekā veicot KAŠ (43,5 \% pret 60,5 \%; p < 0,001) (Kawashima, 2021).

Jāatzīmē, ka sekmīgo HTO revaskularizāciju un rekanalizāciju skaits Syntax pētījumā iekḷautajiem pacientiem bija neliels - tikai $49 \%$ sekmīgu HTO PKI procedūru un 68 \% sekmīgu ķirurgisisku rekanalizāciju (Farooq, 2013), kas, 
visticamāk, neḷauj novērtēt sekmīgas revaskularizācijas vai rekanalizācijas ilgtermiņa ieguvumus.

Citā analīzē, kura veikta Ķīnā un kurā iekḷauti 2659 HTO pacienti, tie tika novēroti piecus gadus (Guan, 2021). Atšķirībā no tradicionālā pacientu sadalījuma divās grupās - pēc sekmīgām un pēc nesekmīgām procedūrām - šajā novērojumā pacienti tika sadalīti trijās grupās:

- optimāla rekanalizācija (58,7 \%): HTO un sānu zaru (ja tādi ir) reperfūzija ar TIMI 3 plūsmas pakāpi;

- suboptimāla rekanalizācija (15,0\%): HTO reperfūzija ar TIMI 1-2 plūsmu un / vai atlieku stenozi > 30 \% un / vai palikuši okludēti lieli sānu zari;

- nesekmīgas procedūras (26,3\%): procedūras laikā nav izdevies šķērsot HTO ar balona katetru.

Piecu gadu laikā veiksmīga HTO rekanalizācija nebija saistīta ar samazinātu kardiālas nāves vai miokarda infarkta risku, salīdzinot ar nesekmīgām procedūrām, taču šis rādītājs bija ievērojami augstāks tiem, kuriem bija suboptimāli rezultāti (10,1\%), salīdzinājumā ar tiem, kuriem bija optimāla rekanalizācija $(6,5 \% ; p=0,02)$, un tiem, kuriem procedūras bija nesekmīgas $(6,3 \% ; \mathrm{p}=0,03)$. Arī periprocedurāli miokarda infarkti un atkārtotas revaskularizācijas novērojuma periodā vairāk bija suboptimālās rekanalizācijas kohortā. Kā galvenais miokarda infarkta cēlonis suboptimālajā grupā bija tieši sānu zaru oklūzijas.

Pētījumā secināts, ka viens no svarīgākajiem pasākumiem, kas varētu palielināt optimāla rezultāta HTO PKI skaitu, ir rūpīga pirmsprocedūras plānošana, izmantojot kādu no HTO sarežǵîtības vērtēšanas sistēmām vai koronārās datortomogrāfijas angiogrāfiju. Tāpat pētījums sniedza pierādījumu: ja nav optimālas HTO rekanalizācijas, lēmums pārtraukt procedūru var būt labākā izvēle gadījumos, kad procedūras turpināšana un stentēšana var novest 
pie "ne optimāla" angiogrāfiska rezultāta. Atzīmējams, ka pētījuma ziṇojumā nebija iekḷauta informācija par procedūras ietekmi uz pacienta simptomiem (stenokardijas klasi) (Guan, 2021).

Mūsu pētījumā atsevišķa suboptimālas HTO revaskularizācijas grupa netika izdalīta. Nelielais nopietno komplikāciju skaits tomēr netieši liecina par relatīvi saudzīgu HTO PKI veikšanas stratēgiju. Tas, iespējams, ir ḷāvis izvairīties no suboptimāla rezultāta pacientu iekḷaušanas sekmīgo procedūru grupā, kas savukārt izdzīvotību sekmīgo procedūru grupā varētu samazināt.

Nesen publicēta metaanalīze par 25 pētījumiem, kuros kopā iekḷauti 19806 pacienti ar stabilu KSS un kuros visos salīdzināta revaskularizācija kopā ar medikamentozu terapiju pret tikai medikamentozu terapiju un analizēta gan kardiāla mirstība, gan spontāni miokarda infarkti un to saistība ar kardiālu nāvi (Navarese et al., 2021). Trīs no 25 pētījumiem bijuši HTO pētījumi, taču pacienti ar HTO bijuši iekḷauti arī daḷā no pārējiem. Metaanalīze pārliecinoši parāda zemāku kardiālo mirstību un mazāku spontānu miokarda infarktu skaitu revaskularizēto pacientu grupā. Mūsu pētījumā spontānu miokarda infarktu gadījumi novērojumu periodā netika uzskaitīti, speciāli analizētas netika kardiālas nāves, bet gan kopējā kardiovaskulārā mirstība. Mūsu pētījums parādīja lielāku gan kopējo $(\mathrm{p}=0,033)$, gan kardiovaskulāro mirstību $(\mathrm{p}=0,06)$ nesekmīgo HTO PKI grupā, tajā pašā laikā nāvju skaits onkoloǵisku iemeslu dēl abās grupās neatšḳīās. Kopumā varam uzskatīt, ka 25 pētījumu metaanalīzes dati saskan ar mūsu pētījuma rezultātiem.

Pētījumos, kuros salīdzināti invazīvas un medikamentozas un tikai medikamentozas ārstēšanas ilgtermiņa rezultāti, līdz šim pamatā tika vērtēta kopējā mirstība. Tas, iespējams, ir viens no iemesliem, kāpēc invazīvas ārstēšanas stratēǵijas priekšrocības līdz šim nav bijušas novērtētas un pierādītas. Skaidrs, ka nekardiālu nāvju skaits ar katru gadu pieaug un ilgstoša novērojumu laika gadījumā mirstība neizbēgami tuvosies $100 \%$ neatkarīgi no ārstēšanas. 
Savā pētījumā salīdzinājām pacientus līdz un pēc 65 gadu vecuma. Līdz 65 gadu vecumam pacientiem pēc nesekmīgām HTO PKI procedūrām bija par $49 \%$ lielāka kopējā mirstība, bet pēc 65 gadu vecuma pacientiem pēc nesekmīgām procedūrām bija par 32 \% lielāka mirstība. Tas ir loǵiski, jo ilgstoša novērojuma laikā, kā tas bija mūsu pētījumā, vecāki pacienti mirst vairāk neatkarīgi no procedūras rezultāta. Precīzāks invazīvās ārstēšanas ilgtermiņa rezultāta rādītājs, visticamāk, būtu kardiāla nāve un / vai atkārtotu spontānu miokarda infarktu biežums.

Retrogrādā metode HTO PKI veikšanai lietota 183 pacientiem, turklāt 31 pacientam tā bijusi primārā startēǵija. Procentuāli sekmīgo procedūru skaits bijis vienāds gan gadījumos, kad retrogrādā metode lietota uzreiz pēc nesekmīga antegrāda mēǵinājuma, gan arī gadījumos, kad tā izmantota kā primārā stratēgija, kas liecina, ka lēmums uzreiz sākt procedūru retrogrādi šajos gadījumos ir bijis pareizs. Salīdzinot anatomiskos sarežǵītības kritērijus retrogrādo HTO PKI pacientiem, redzams, ka pacientiem, kuriem procedūra uzreiz sākta retrogrādi, biežāk bijusi neskaidra proksimālā ieeja, biežāk HTO bijusi lokalizēta ostiāli un biežāk iepriekš jau bijis nesekmīgs HTO PKI mēǵinājums. Savukārt tāds sarežğîtîbas rādītājs kā okludētā segmenta garums abās grupās neatšḳiras, kas nozīmē, ka tas nav kalpojis par labu izvēlei uzreiz sākt procedūru retrogrādi.

Kaut arī retrogrādās metodes lietošanas grupā konstatēts lielāks nopietnāko komplikāciju - perforāciju skaits, nāves gadījumi intrahospitālajā etapā nav konstatēti un arī ilgtermiņa izdzīvotību tas nav ietekmējis. Objektivitātes dēḷ izdzīvotība salīdzināta gan starp sekmīgām antegrādām un sekmīgām retrogrādām procedūrām, gan starp nesekmīgām antegrādām un nesekmīgām retrogrādām procedūrām. Nesekmīga rezultāta pacientu grupā izdzīvotība pacientiem, kuriem lietota retrogrādā metode, bija pat labāka. Laikus veikta komplikāciju diagnostika un sekmīga to ārstēšana spēj mazināt pacienta risku līdz minimumam. 
Nesen publicēti dati no Nīderlandē veikta reǵistra, kurā bija iekḷauti 212 HTO pacienti, kuriem 2013.-2019. gadā veiktas sekmīgas HTO PKI un kuriem pirms procedūras un trīs mēnešus pēc procedūras tika veikti PET izmeklējumi miokarda išēmijas noteikšanai. Pacientu vidējais vecums bija 62 gadi, un $84 \%$ pacientu bija vīrieši. $16 \%$ pacientu bija asimptomātiski, $41 \%$ bija saglabāta izsviedes frakcija, un $59 \%$ tā bija nedaudz samazināta (EF virs $40 \%$ ). Pēc 2,8 gadu vidējā novērošanas perioda mirstība bija $8 \%$, bet $2 \%$ pacientu bija pārcietuši nefatālus miokarda infarktus. Labāka izdzīvotība tika konstatēta pacientiem, kam bija panākta perfūzijas uzlabošanās un nebija reziduālās išēmijas ( $\mathrm{p}=0,04 ;$ HR 0,$34 ; 95 \%$ TI $0,13-0,93$ ). Tāpat labāka izdzīvotība konstatēta pacientiem, kuriem pēc HTO PKI tika panākts hiperēmijas miokarda asins plūsmas (hMBF) pieaugums virs populācijas vidējā līmeņa ( $<<0,01$; HR 0,16; 95 \% TI 0,05-0,54) (Schumacher et al., 2021). Kaut arī šis bija nevis randomizēts pētījums, bet reǵistrs, tas uzskatāmi parāda, ka pareizi izvēlētiem pacientiem, veicot tehniski perfektu procedūru centrā ar lielu HTO PKI veikšanas pieredzi, iespējams gūt ilgtermiņa ieguvumu.

Skaidrojums, kāpēc atsevišḳos registros tiek konstatēts ieguvums no HTO PKI, bet randomizētos pētījumos ne, varētu būt to plašums. Randomizētos pētījumos, kuros piedalās daudz centru, nenovēršami pastāv gan pacientu atlases, gan dažādas datu interpretācijas riski, tāpat arī atšḳirības revaskularizācijas procedūru veikšanas kvalitātē.

Mūsu pētījumā išēmijas testi ne pirms, ne pēc HTO PKI procedūras netika veikti un galvenā indikācija procedūras veikšanai bija simptomi. Nīderlandē veiktajā pētījumā $16 \%$ pacientu bija asimptomātiski, taču kvalitatīvi veiktie išēmijas testi parādīja, ka praktiski visiem HTO pacientiem (93\%) bija inducējama išēmija. Tas liek apšaubît išēmijas testu lietderību vienas artērijas slimības HTO pacientiem, ja ir simptomi un saglabāta miokarda kontraktilitāte (Schumacher et al., 2021). 
Neskatoties uz labu angiogrāfisko rezultātu, 50 \% pacientu pēc sekmīgas HTO PKI Nīderlandes pētījumā tomēr saglabājās reziduālā išēmija, un šobrīd nav precīzu metožu, lai prognozētu, kurš pacients būs ieguvējs un kurš ne no HTO PKI procedūras. Atbilde, visticamāk, meklējama HTO sarežg̊ītības novērtēšanā.

Pirmā HTO sarežğìtîbas vērtēšanas sistēma J-CTO score tika izveidota, lai prognozētu iespēju šķērsot HTO ar stīgu un tā varētu prognozēt procedūras tehnisko iznākumu (Joyal, 2010). Procedūras ar augstāku HTO punktu skaitu ir tehniski sarežğītākas un ar mazāku sekmīguma līmeni. Sarežǵītākas procedūras saistītas ar agresīvāku tehniku lietošanu, lielāku materiālu patēriņu, garāku procedūras laiku, lielāku starojumu un kontrasta patēriņu, kā arī lielāku komplikāciju risku.

Mūsu pētījumā tika vērtēts, vai tehniski sarežğìtas HTO PKI ietekmē ilgtermiņa rezultātus. Nav noslēpums, ka nesekmīgas HTO PKI iemesls un / vai procedūras pārtraukšanas iemesls nereti ir komplikācijas. Lai objektīvi novērtētu, vai tehniski sarežğîtu HTO invazīva ārstēšana tiešām ietekmē pacienta izdzīvotību, salīdzināti vienīgi dažādas sarežğîtības sekmīgo procedūru ilgtermiṇa rezultāti.

Netika atrastas ilgtermiṇa rezultātu atšķirīibas starp dažādas sarežğîtīibas procedūrām, analizējot gadījumus ar J-CTO un CL rādītāju sistēmām. Tajā pašāà laikā, analizējot gadījumus ar PROGRESS CTO un CASTLE rādītājiem, sarežğîtākiem pacientiem bija statistiski sliktāka ilgtermiņa prognoze. Daži no HTO sarežğîtības rādītājiem iekḷauti vairākās vērtēšanas sistēmās, tomēr daži ir unikāli. PROGRESS CTO vērtēšanas skala atškiras no citām, jo balstās tikai un vienīgi uz četriem anatomiskiem kritērijiem, kuros ietilpst kolaterāḷu novērtējums un HTO lokalizācija kreisajā apliecošajā koronārajā artērijā, kas kā sarežğîtības kritēriji nav iekḷauti nevienā citā HTO vērtēšanas skalā. Šie divi faktori procedūru noteikti sarežğī, jo PROGRESS CTO skalas prognostiskā 
vērtība no citām skalām būtiski neatšḳīāa - lielāks PROGRESS CTO punktu skaits korelēja ar zemāku sekmīgo procedūru skaitu, tomēr, salīdzinot ar citām novērtēšanas sistēmām, korelācija bija zemāka, kas varētu liecināt par zemāku kolaterāḷu trūkuma un LCX lokalizācijas kā sarežgîitības rādītāju nozīmīgumu. Ilgtermiņa rezultāti tomēr pacientiem ar augstāku PROGRESS CTO vērtējumu bija krietni sliktāki, nekā pacientiem ar zemu vērtējumu. Salīdzinot dažādas novērtēšanas skalas pēc maksimāli iespējamā sarežǵītības punktu skaita, PROGRESS vērtējumam tas ir vismazākais - maksimāli, tikai 4 punkti, līdz ar to pacientu sadalījums nav tik plašs, kā citos vērtējumos un katra atsevišķa sarežǵìtības punkta vērtība pieaug. Hroniskas totālas oklūzijas kreisajā apliecošajā koronārajā artērijā sastopamas retāk, nekā kreisajā priekšējā lejupejošajā un labajā koronārajā artērijā. Nav pētījumu, kas apliecinātu sliktāku prognozi pcientiem ar LCX HTO. Retrogrādai pieejai izmantojamu kolaterāḷu esamība vai neesamība savukārt ir loti nozīmīgs faktors, kas iekḷauts piln̄̄gi visos HTO šķērsošanas algoritmos. Izmantojamu kolaterāḷu trūkums piel̦auj tikai antegrādo HTO šķērsošanas metožu izmantošanu. Tas sarežğìtākos gadījumos var palielināt sānu zaru slēgšanās un periprocedurālu miokarda infarktu risku, kas, kā apliecina iepriekš minētais Ķīnā veiktais pētījums, var novest pie suboptimāla procedūras iznākuma un procedūras ilgtermiņa rezultātus pasliktina.

CASTLE skalas vērtējums ir atšķirīgs ar to, ka tas kā sarežğîtības faktorus ietver pacienta vecumu un koronāro artēriju šuntēšanas operāciju anamnēzē. Vecums un novecošana, kā zināms, ir neatkarīgs kardiovaskulāru notikumu riska faktors (Stahli, 2018).

KAŠ anamnēzē vērtējama kā vairāku nozīmīgu riska faktoru kopums, jo HTO pacienti ar KAŠ operācijām anamnēzē ir gan gados vecāki, gan biežāk pārcietuši miokarda infarktu, gan arī viņiem biežāk iepriekš jau ir veiktas PKI. Lai gan lielākajai daḷai HTO pacientu (60\%) nav iepriekš dokumentētu miokarda infarktu (Fefer et al., 2012), vairāk nekā 90 \% HTO pacientu rētaudus 
HTO zonā var konstatēt (Schumacher et al., 2021). HTO pēc pārciesta miokarda infarkta ir zināms kā neatkarīgs riska faktors kambaru aritmijām, kas 2-3 reizes palielina ventrikulāru aritmiju rašanos pat pēc radiofrekvences ablācijas (di Marko et al., 2017, 2019). Pacientiem ar HTO un implantētu defibrillatorukardioverteri pēkšņas sirds nāves primārai vai sekundārai profilaksei biežāk tiek konstatētas izlādes, salīdzinot ar pacientiem ar išēmisku kardiomiopātiju un bez HTO (Fefer et al., 2012). Visticamāk, ka nekrotiskā zona un rēta darbojas kāa kambaru aritmijas ierosinātājs (di Marko et al., 2017, 2019). Iespējams, tāpēc pacientiem ar augstāku CASTLE score punktu skaitu ilgtermin̄ā rezultāti ir sliktāki.

Nedaudz negaidīts pētījuma atklājums bija ilgtermiņa HTO PKI rezultātu salīdzinājums pēc sekmīgām un nesekmīgām procedūrām vīriešiem un sievietēm. Sievietēm netika konstatētas būtiskas atšķirības izdzīvotībā sekmīgo un nesekmīgo procedūru grupās. Rūpīgi izpētot citu reǵistru datus, redzams tomēr, ka līdzīgi rezultāti iegūti arī citos pētījumos. Pēc dažādu reǵistru datiem, sievietēm HTO atrod retāk un sieviešu īpatsvars HTO PKI reǵistros parasti svārstās starp 10 - 20 \%. Tā, piemēram, no 1791 HTO pacienta, kam ASV un Korejā laikā no 1998. līdz 2007. gadam tika veiktas HTO PKI procedūras, tikai $14 \%$ bija sievietes. Salīdzinot sekmīgās un nesekmīgās procedūras, lielo kardiovaskulāro notikumu 2,9 gadu ilgā apsekojuma periodā krietni mazāk bija sekmīgu procedūru grupā gan starp vīriešiem, gan sievietēm (vīriešiem 13,1\% pret $24,4 \%(\mathrm{p}<0,01)$, sievietēm $12,3 \%$ pret $15,5 \%(\mathrm{p}=0,04))$, tomēr vīriešu grupā tika novērots krietni lielāks notikumu samazinājums $(\mathrm{p}<0,01)$ (Claessen, 2012).

Līdzīgā pētījumā Ķīnā, kurš publicēts 2019. gadā un kurā tika iekḷauti 1702 pacienti, 23,5 \% bija sieviešu. Šajā pētījumā puse pacientu saṇēma vienīgi optimālu medikamentozu terapiju, otrai pusei tika veiktas HTO PKI. Pacienti tika sadalīti trijās grupās: tikai medikamentozi ārstētie, pacienti pēc sekmīgām 
HTO PKI, pacienti pēc nesekmīgām HTO PKI. Salīdzinātas tika medikamentozās terapijas grupa ar sekmīgo HTO PKI grupu. Sieviešu grupā netika konstatētas nozīmīgas atšķirības starp medikamentozo terapiju un veiksmīgu HTO PKI grupām attiecībā uz kardiālu nāvi (medikamentoza terapija pret veiksmīgu PKI: 6,8 \% pret 3,9 \%, p = 0,287) un lieliem kardiovaskulāriem notikumiem $(20,9 \%$ pret $21,3 \%, p=0,810)$. Vīriešu grupā kardiālas nāves gadījumi (medikamentoza terapija pret veiksmīgu PKI: 6,6\% pret 3,8\%, $\mathrm{p}=0,066)$ abās grupās bija līdzīgi, toties lielo kardiovaskulāro notikumu skaits $(30,0 \%$ pret $18,5 \%, p$ < 0,001) medikamentozās terapijas grupā bija ievērojami augstāks (Guo et al., 2019).

Gan mūsu, gan abos pieminētajos pētījumos iekḷauto sieviešu vidējais vecums bija lielāks, nekā vīriešu. Tas apstiprina jau iepriekš zināmo faktu par estrogēnu protektīvo ietekmi uz aterosklerozes veidošanos sievietēm līdz menopauzei un vēlāku aterosklerozes attīstību. Lielāks vecums ilgā novērojuma periodā mazina izdzīvotības atšķirības starp sekmīgo un nesekmīgo HTO PKI pacientu grupām.

46 no pētījumā iekḷautajiem pacientiem $(8,35 \%)$ anamnēzē bija KAŠ operācijas. Salīdzinot ar citiem HTO PKI reǵistriem, kur KAŠ pacientu skaits svārstās no 7,5\% Japānā līdz 37 \% Ziemeḷamerikā (Dautov, 2016), šis procents nav liels, kas skaidrojams ar PKI un KAŠ veikšanas vēsturisko attiecību Latvijā, kur tā ir 7-8 : 1. Salīdzinot pacientus ar un bez KAŠ anamnēzē, statistiski ticamu atšķirību starp grupām nebija, taču pēc visiem analizētajiem parametriem redzams, ka šuntētie pacienti kopumā bija gados vecāki un slimāki, viṇiem biežāk bija KSS riska faktori-hipertensija, dislipidēmija, viṇi biežāk bija pārcietuši miokarda infarktus un viņiem biežāk jau iepriekš bija veiktas PKI. Statistiski ticami biežāk šiem pacientiem tika lietota retrogrādā pieeja. Sekmīgo procedūru skaits šiem pacientiem bija zemāks, un ilgtermiṇa izdzīvotība pēc sekmīgām HTO PKI procedūrām bija sliktāka. Šuntētie pacienti starp mūsu 
pētījumā iekḷauto 551 pacientu bija tikai 45 (8,2 \%), kas neḷauj veikt šīs pacientu grupas objektīvu un pilnvērtīgu analīzi. 


\section{Secinājumi}

1. Sekmīga HTO revaskularizācija, salīdzinot ar nesekmīgu, uzlabo pacientu izdzīvotību.

2. Retrogrādās metodes lietošana uzlabo procedūru rezultātus un nepasliktina prognozi. Retrogrādā metode apsverama kā primārā stratēgija gadījumos, kad HTO lokalizēta ostiāli un / vai proksimālā ieeja ir neskaidra.

3. HTO sarežğîtība, kas noteikta, izmantojot J-CTO, PROGRESS CTO, CL un CASTLE skalas, tieši korelē ar HTO PKI iznākumu. HTO sarežğîtība, kas noteikta, izmantojot PROGRESS CTO un CASTLE skalas, var ietekmēt pacienta izdzīvotību, pateicoties šajās skalās iekḷautajiem sarežgîitības kritērijiem - kolaterālēm, vecumam un KAŠ anamnēzē.

4. HTO revaskularizācija vīriešiem nodrošina labāku izdzīvotību, nekā sievietēm. Cukura diabēta esamība vai neesamība HTO PKI ilgtermiṇa rezultātus neietekmē. Pacientiem līdz 65 gadu vecumam un vecākiem izdzīvotība pēc sekmīgas PKI procedūras nav saistīta ar pacienta vecumu, bet gan ar procedūras iznākumu. Pacienti ar HTO un koronāro artēriju šuntēšanas operāciju anamnēzē vērtējami kā paaugstinātas sarežğītības HTO PKI pacienti.

\section{Hipotēzes}

Hipotēze "sekmīga hronisku totālu koronāro artēriju oklūziju invazīva rekanalizācija neatkarīgi no tās sarežğîitības un neatkarīgi no izmantotās perkutānās koronārās intervences tehnikas ir efektīva hronisku totālu koronāro artēriju oklūziju ārstēšanas metode un uzlabo pacientu dzīvildzi" pētījuma ietvaros tika apstiprināta. Pacientiem pēc sekmīgām HTO PKI procedūrām tika novērota statistiski ticami labāka izdzīvotība, nekā pēc nesekmīgām HTO PKI procedūrām. 
Hipotēze "retrogrādās metodes lietošana uzlabo hronisku totālu koronāro artēriju oklūziju perkutānās koronārās intervences rezultātus, nepasliktina ilgtermiņa prognozi un atsevišķos gadījumos lietojama kā primārā perkutānās koronārās intervences stratēg̣ija" pētījuma ietvaros arī tika apstiprināta. Konstatēta saistība starp retrogrādās metodes lietošanu un sekmīgo procedūru skaita pieaugumu. Pacientiem, kuriem lietota retrogrādā metode, netika konstatēta sliktāka izdzīvotība. Sekmīgums primāru retrogrādu HTO PKI gadījumā konstatēts līdzịgs retrogrādās metodes izmantojumā uzreiz pēc nesekmīga antegrāda mēǵinājuma.

\section{Rezultātu iespējamais praktiskais lietojums}

Balstoties uz darba rezultātiem, apstiprināta sekmīgu HTO PKI nozīme pacientu izdzīvotības uzlabošanai. Pierādīts retrogrādās metodes lietošanas nozīmīgums HTO revaskularizācijas rezultātu uzlabošanai. Sekmēta retrogrādās metodes ieviešana klīniskajā praksē visā Latvijā. Pierādīta HTO sarežğîtīibas novērtēšanas nozīme, lai prognozētu gan procedūras iznākumu, gan ilgtermiṇa rezultātus. 


\section{Publikācijas un ziṇojumi par promocijas darba tēmu}

\section{Zinātniskās publikācijas izdevumos, kas iekḷauti starptautiskās datubāzēs:}

1. Kalnins, A., Strele, I., Lejnieks, A. 2019. Comparison among Different Scoring Systems in Predicting Procedural Success and Long-Term Outcomes after Percutaneous Coronary Intervention in Patients with Chronic Total Coronary Artery Occlusions. Medicina (Kaunas, Lithuania). 55(8), 494. https://doi.org/10.3390/ medicina55080494.

2. Kalniņš, A., Strēle, I., Kurcalte, I., Lejnieks, A., Ērglis, A. 2018. Chronic Total Coronary Artery Occlusion Recanalization with Percutaneous Coronary Intervention - Single Centre 10-Year Experience. Proceedings of the Latvian Academy of Sciences. Section B. Natural, Exact, and Applied Sciences. 72(1), 1-8. doi: https://doi.org/10.1515/prolas-2018-0001.

3. Brilakis, E. S., Mashayekhi, K., Tsuchikane, E., Abi Rafeh, N., Alaswad, K., Araya, M., Avran, A., Azzalini, L., Babunashvili, A. M., Bayani, B., Bhindi, R., Boudou, N., Boukhris, M., Božinović, N. Ž., Bryniarski, L., Bufe, A., Buller, C. E., Burke, M. N., Büttner, H. J., Cardoso, P., Carlino, M., Christiansen, E. H., Colombo, A., Croce, K., Damas de Los Santos, F., de Martini, T., Dens, J., di Mario, C., Dou, K., Egred, M., ElGuindy, A. M., Escaned, J., Furkalo, S., Gagnor, A., Galassi, A. R., Garbo, R., Ge, J., Goel, P. K., Goktekin, O., Grancini, L., Grantham, J. A., Hanratty, C., Harb, S., Harding, S. A., Henriques, J. P. S., Hill, J. M., Jaffer, F. A., Jang, Y., Jussila, R., Kalnins, A., Kalyanasundaram, A., Kandzari, D.E., Kao, H. L., Karmpaliotis, D., Kassem, H. H., Knaapen, P., Kornowski, R., Krestyaninov, O., Kumar, A. V. G., Laanmets, P., Lamelas, P., Lee, S. W., Lefevre, T., Li, Y., Lim, S. T., Lo., S., Lombardi, W., McEntegart, M., Munawar, M., Navarro Lecaro, J. A., Ngo, H. M., Nicholson, W., Olivecrona, G. K., Padilla, L., Postu, M., Quadros, A., Quesada, F. H., Prakasa Rao, V. S., Reifart, N., Saghatelyan, M., Santiago, R., Sianos, G., Smith, E. C., Spratt, J., Stone, G. W., Strange, J. W., Tammam, K., Ungi, I., Vo, M., Vu, V. H., Walsh, S., Werner, G. S., Wollmuth, J. R., Wu, E. B., Wyman, R. M., Xu, B., Yamane, M., Ybarra, L. F., Yeh, R. W., Zhang, Q., Rinfret, S. 2019. Guiding Principles for Chronic Total Occlusion Percutaneous Coronary Intervention. Circulation. 140(5),420-433. doi: 10.1161/CIRCULATIONAHA.119.039797. Epub 2019 Jul 29. PMID: 31356129.

4. Galassi, A. R., Sianos, G., Werner, G. S., Escaned, J., Tomasello, S. D., Boukhris, M., Castaing, M., Büttner, J. H., Bufe, A., Kalnins, A., Spratt, J. C., Garbo, R., HildickSmith, D., Elhadad, S., Gagnor, A., Lauer, B., Bryniarski, L., Christiansen, E. H., Thuesen, L., Meyer-Geßner, M., Goktekin, O., Carlino, M., Louvard, Y., Lefèvre, T., Lismanis, A., Gelev, V. L., Serra, A., Marzà, F., di Mario, C., Reifart, N. Euro CTO Club. 2015. Retrograde Recanalization of Chronic Total Occlusions in Europe: Procedural, In-Hospital, and Long-Term Outcomes from the Multicenter ERCTO Registry. Journal of the American College of Cardiology.65(22), 2388-2400. https://doi.org/10.1016/j.jacc.2015.03.566. 
5. Werner, G. S., Avran, A., Mashayekhi, K., Reifart, J., Galassi, A. R., Boudou, N., Meyer-Gessner, M., Garbo, R., Buettner, J. H., Bufe, A., Spratt, J. C., Bryniarski, L., Kalnins, A., Lismanis, A., Christiansen, E. H., Martin-Yuste, V., Isaaz, K., Sianos, G., Gagnor, A., di Mario, C., Reifart, N. 2021. Radiation Exposure for Percutaneous Interventions of Chronic Total Coronary Occlusions in a Multicenter Registry: The Influence of Operator Variability and Technical Set-up. The Journal of Invasive Cardiology. 33(3), E146-E154.

6. Wu, E. B., Brilakis, E. S., Mashayekhi, K., Tsuchikane, E., Alaswad, K., Araya, M., Avran, A., Azzalini, L., Babunashvili, A. M., Bayani, B., Behnes, M., Bhindi, R., Boudou, N., Boukhris, M., Bozinovic, N. Z., Bryniarski, L., Bufe, A., Buller, C. E., Burke, M. N., Buttner, A., Cardoso, P., Carlino, M., Chen, J.Y., Christiansen, E. H., Colombo, A., Croce, K., de Los Santos, F. D., de Martini, T., Dens, J., di Mario, C., Dou, K., Egred, M., Elbarouni, B., El Guindy, A. M., Escaned, J., Furkalo, S., Gagnor, A., Galassi, A. R., Garbo, R., Gasparini, G., Ge, J., Ge, L., Goel, P. K., Goktekin, O., Gonzalo, N., Grancini, L., Hall, A., Hanna Quesada, F. L., Hanratty, C., Harb, S., Harding, S. A., Hatem, R., Henriques, J. P. S., Hildick-Smith, D., Hill, J. M., Hoye, A., Jaber, W., Jaffer, F. A., Jang, Y., Jussila, R., Kalnins, A., Kalyanasundaram, A., Kandzari, D. E., Kao, H. L., Karmpaliotis, D., Kassem, H. H., Khatri, J., Knaapen, P., Kornowski, R., Krestyaninov, O., Kumar, A. V. G., Lamelas, P. M., Lee, S. W., Lefevre, T., Leung, R., Li, Y., Li, Y., Lim, S. T., Lo, S., Lombardi, W., Maran, A., McEntegart, M., Moses, J., Munawar, M., Navarro, A., Ngo, H. M., Nicholson, W., Oksnes, A., Olivecrona, G. K., Padilla, L., Patel, M., Pershad, A., Postu, M., Qian, J., Quadros, A., Rafeh, N. A., Råmunddal, T., Prakasa Rao, V. S., Reifart, N., Riley, R. F., Rinfret, S., Saghatelyan, M., Sianos, G., Smith, E., Spaedy, A., Spratt, J., Stone, G., Strange, J. W., Tammam, K. O., Thompson, C. A., Toma, A., Tremmel, J. A., Trinidad, R. S., Ungi, I., Vo, M., Vu, V.H., Walsh, S., Werner, G., Wojcik, J., Wollmuth, J., Xu, B., Yamane, M., Ybarra, L. F., Yeh, R. W., Zhang, Q. 2021. Global Chronic Total Occlusion Crossing Algorithm: JACC State-of-the-Art Review. Journal of the American College of Cardiology, 78(8), 840-853. https://doi.org/ 10.1016/j.jacc.2021.05.055.

\section{Zinātniski raksti Latvijā izdotos recenzējamos izdevumos:}

1. Kalnins, A., Strele, I., Lejnieks, A., Lukstins, G. 2013. Chronic total coronary artery occlusion recanalization with percutaneous coronary intervention using anterograde and retrograde approach - Riga EAST Clinical University Hospital Experience. Acta Chirurgica Latviensis. Volume 13 (1) de Gruyter - Dec 1, 2013.

2. Kalniņš, A., Lismanis, A., Lejnieks, A., Ērglis, A. 2015. Retrogrādās metodes lietošana hronisku totālu koronāro artēriju oklūziju invazīvā ārstēšanā. $R S U$ Zinātniskie raksti. 53-63. 


\section{Tēzes un ziṇojumi starptautiskās konferencēs:}

1. Kalniņš, A., Strēle, I., Lejnieks, A., Kurcalte, I., XXIV Nordic - Baltic Congress of Cardiology: CTO PCI Retrograde approach. 13.06.2013.-15.06.2013. Oslo, Norway. Cardiology, International Journal of Cardiovascular Medicine, Surgery, Pathology and Pharmacology 39, PC-006.

\section{Tēzes un ziṇojumi vietējās konferencēs:}

1. Kalniņš, A., Strēle, I., Lejnieks, A., Kurcalte, I., Strēlnieks, A. RSU 2013. gada zinātniskā konference. Mutisks ziņojums. Hronisku totālu koronāro artēriju oklūziju invazīvas ārstēšanas metožu salīdzinājums. Zinātniskās konferences tēzes (Rīga, 2013. g. 21.-22. martā) / Rīgas Stradiṇa universitāte. - Rīga, 2013. - 105. lpp.

2. Kalniņš, A., Kurcalte, I., Strēlnieks, A., Lejnieks, A. RSU 2016. gada zinātniskā konference. Mutisks ziņojums. Hronisku totālu koronāro artēriju oklūziju invazìva ārstēšana, lietojot retrogrādo metodi. Zinātniskās konferences tēzes (Rīga, 2016.g. 17.-18. martā) / Rīgas Stradiṇa universitāte. - Rīga, 2016. - 33. lpp. 


\section{Literatūras saraksts}

1. Christopoulos, G., Karmpaliotis, D., Alaswad, K., Lombardi, W. L., Grantham, J. A., Rangan, B. V., Kotsia, A. P., Lembo, N., Kandzari, D. E., Lee, J., Kalynych, A., Carlson, H., Garcia, S., Banerjee, S., Thompson, C. A. and Brilakis, E. S. 2014. The efficacy of "hybrid" percutaneous coronary intervention in chronic total occlusions caused by in-stent restenosis: insights from a US multicenter registry. Catheterization and Cardiovascular Interventions. 84(4), 646-651.

2. Christofferson, R. D., Lehmann, K. G., Martin, G. V., Every, N., Caldwell, J. H. and Kapadia, S. R. 2005. Effect of chronic total coronary occlusion on treatment strategy. The American Journal of Cardiology. 95(9), 1088-1091.

3. Christopoulos, G., Karmpaliotis, D., Alaswad, K., Yeh, R. W., Jaffer, F. A., Wyman, R. M., Lombardi, W. L., Menon, R. V., Grantham, J. A., Kandzari, D. E., Lembo, N., Moses, J. W., Kirtane, A. J., Parikh, M., Green, P., Finn, M., Garcia, S., Doing, A., Patel, M., Bahadorani, J., Brilakis, E. S. 2015. Application and outcomes of a hybrid approach to chronic total occlusion percutaneous coronary intervention in a contemporary multicenter US registry. International Journal of Cardiology. 198, 222-228.

4. Claessen, B. E., van der Schaaf, R. J., Verouden, N. J., Stegenga, N. K., Engstrom, A. E., Sjauw, K. D., Kikkert, W. J., Vis, M. M., Baan, J., Jr, Koch, K. T., de Winter, R. J., Tijssen, J. G., Piek, J. J. \& Henriques, J. P. 2009. Evaluation of the effect of a concurrent chronic total occlusion on long-term mortality and left ventricular function in patients after primary percutaneous coronary intervention. JACC. Cardiovascular Interventions. 2(11), 1128-1134.

5. Claessen, B. E., Chieffo, A., Dangas, G. D., Godino, C., Lee ,S. W., Obunai, K., Carlino, M., Chantziara, V., Apostolidou, I., Henriques, J. P., Leon, M. B., di Mario, C., Park, S. J., Stone, G. W., Moses, J. W., Colombo, A., Mehran, R. 2012. Multinational CTO Registry. Gender differences in long-term clinical outcomes after percutaneous coronary intervention of chronic total occlusions. The Journal of Invasive Cardiology. 24(10), 484-488.

6. Dautov, R., Manh Nguyen, C., Altisent, O., Gibrat, C. \& Rinfret, S. 2016. Recanalization of Chronic Total Occlusions in Patients With Previous Coronary Bypass Surgery and Consideration of Retrograde Access via Saphenous Vein Grafts. Circulation. Cardiovascular Interventions. 9(7), e003515.

7. Di Marco, A., Anguera, I., Teruel, L., Muntane, G., Campbell, N. G., Fox, D. J., Brown, B., Skene, C., Davidson, N., Leon, V., Dallaglio, P., Elzein, H., GarciaRomero, E., Gomez-Hospital, J. A. \& Cequier, A. 2017. Chronic total occlusion in an infarct-related coronary artery and the risk of appropriate ICD therapies. Journal of Cardiovascular Electrophysiology. 28(10), 1169-1178. 
8. Di Marco, A., Paglino, G., Oloriz, T., Maccabelli, G., Baratto, F., Vergara, P., Bisceglia, C., Anguera, I., Sala, S., Sora, N., Dallaglio, P., Marzi, A., Trevisi, N., Mazzone, P. and Della Bella, P. 2015. Impact of a chronic total occlusion in an infarctrelated artery on the long-term outcome of ventricular tachycardia ablation. Journal of Cardiovascular Electrophysiology. 26(5), 532-539.

9. Fefer, P., Knudtson, M. L., Cheema, A. N., Galbraith, P. D., Osherov, A. B., Yalonetsky, S., Gannot, S., Samuel, M., Weisbrod, M., Bierstone, D., Sparkes, J. D., Wright, G. A. and Strauss, B. H. 2012. Current perspectives on coronary chronic total occlusions: the Canadian Multicenter Chronic Total Occlusions Registry. Journal of the American College of Cardiology. 59(11), 991-997.

10. Guan, C., Yang, W., Song, L., Chen, J., Qian, J., Wu, F., Zou, T., Shi, Y., Sun, Z., Xie, L., Gao, L., Cui, J., Zhao, J., Kirtane, A. J., Yeh, R. W., Wu, Y., Yang, Y., Qiao, S., Brilakis, E. S. and Xu, B. 2021. Association of Acute Procedural Results With Long-Term Outcomes After CTO PCI. JACC. Cardiovascular Interventions. 14(3), 278-288.

11. Guo, L., Lv, H., Zhong, L., Wu, J., Ding, H., Xu, J. and Huang, R. 2019. Gender Differences in Long-Term Outcomes of Medical Therapy and Successful Percutaneous Coronary Intervention for Coronary Chronic Total Occlusions. Journal of interventional cardiology. 2019, 2017958. https://doi.org/10.1155/2019/2017958.

12. Henriques, J. P., Hoebers, L. P., Råmunddal, T., Laanmets, P., Eriksen, E., Bax, M., Ioanes, D., Suttorp, M. J., Strauss, B. H., Barbato, E., Nijveldt, R., van Rossum, A. C., Marques, K. M., Elias, J., van Dongen, I. M., Claessen, B. E., Tijssen, J. G., van der Schaaf, R. J. and EXPLORE Trial Investigators. 2016. Percutaneous Intervention for Concurrent Chronic Total Occlusions in Patients With STEMI: The EXPLORE Trial. Journal of the American College of Cardiology. 68(15), 1622-1632.

13. Ivanhoe, R. J., Weintraub, W. S., Douglas, J. S. Jr., Lembo, N. J., Furman, M., Gershony, G., Cohen, C. L., King, S. B. 3rd. 1992. Percutaneous transluminal coronary angioplasty of chronic total occlusions. Primary success, restenosis, and long term clinical follow up. Circulation. 85, 106-115.

14. Jeroudi, O. M., Alomar, M. E., Michael, T. T., El Sabbagh, A., Patel, V. G., Mogabgab, O., Fuh, E., Sherbet, D., Lo, N., Roesle, M., Rangan, B. V., Abdullah, S. M., Hastings, J. L., Grodin, J., Banerjee, S. and Brilakis, E. S. 2014. Prevalence and management of coronary chronic total occlusions in a tertiary Veterans Affairs hospital. Catheterization and Cardiovascular Interventions. 84(4), 637- 643.

15. Joyal, D., Afilalo, J. and Rinfret, S. 2010. Effectiveness of recanalization of chronic total occlusions: a systematic review and meta-analysis. American Heart Journal. 160(1), 179-187.

16. Kahn, J. K., Hartzler, G. O. 1990. Retrograde coronary angioplasty of isolated arterial segments through saphenous vein bypass grafts. Catheterization and Cardiovascular Diagnosis. 20(2), 88-93. 
17. Kalnins, A., Strele, I., Lejnieks, A., Lukstins, G. 2013. Chronic total coronary artery occlusion recanalization with percutaneous coronary intervention using anterograde and retrograde approach-Riga EAST Clinical University Hospital Experience. Acta Chirurgica Latviensis. 13 (1), 17-21.

18. Karmpaliotis, D., Michael, T. T., Brilakis, E. S., Papayannis, A. C., Tran, D. L., Kirkland, B. L., Lembo, N., Kalynych, A., Carlson, H., Banerjee, S., Lombardi, W. and Kandzari, D. E. 2012. Retrograde coronary chronic total occlusion revascularization: procedural and in-hospital outcomes from a multicenter registry in the United States. JACC. Cardiovascular Interventions. 5(12), 1273-1279.

19. Kawashima, H., Takahashi, K., Ono, M., Hara, H., Wang, R., Gao, C., Sharif, F., Mack, M. J., Holmes, D. R., Morice, M. C., Head, S. J., Kappetein, A. P., Thuijs, D., Milojevic, M., Noack, T., Mohr, F. W., Davierwala, P. M., Serruys, P. W., Onuma, Y. and SYNTAX Extended Survival Investigators. 2021. Mortality 10 Years After Percutaneous or Surgical Revascularization in Patients With Total Coronary Artery Occlusions. Journal of the American College of Cardiology. 77(5), 529-540.

20. Kimura, M., Katoh, O., Tsuchikane, E., Nasu, K., Kinoshita, Y., Ehara, M., Terashima, M., Matsuo, H., Matsubara, T., Asakura, K., Asakura, Y., Nakamura, S., Oida, A., Takase, S., Reifart, N., di Mario, C. \& Suzuki, T. 2009. The efficacy of a bilateral approach for treating lesions with chronic total occlusions the CART (controlled antegrade and retrograde subintimal tracking) registry. JACC. Cardiovascular Interventions. 2(11), 1135-1141.

21. Lee, S. H., Yang, J. H., Choi, S. H., Park, T. K., Jang, W. J., Song, Y. B., Hahn, J. Y., Choi, J. H. and Gwon, H. C. 2017. Duration of dual antiplatelet therapy in patients treated with percutaneous coronary intervention for coronary chronic total occlusion. 12(5), e0176737.

22. Lee, P. H., Lee, S. W., Park, H. S., Kang, S. H., Bae, B. J., Chang, M., Roh, J. H., Yoon, S. H., Ahn, J. M., Park, D. W., Kang, S. J., Kim, Y. H., Lee, C. W., Park, S. W. and Park, S. J. 2016. Successful Recanalization of Native Coronary Chronic Total Occlusion Is Not Associated With Improved Long-Term Survival. JACC. Cardiovascular Interventions. 9(6), 530-538.

23. Navarese, E. P., Lansky, A. J., Kereiakes, D. J., Kubica, J., Gurbel, P. A., Gorog, D. A., Valgimigli, M., Curzen, N., Kandzari, D. E., Bonaca, M. P., Brouwer, M., Umińska, J., Jaguszewski, M. J., Raggi, P., Waksman, R., Leon, M. B., Wijns, W. and Andreotti, F. 2021. Cardiac mortality in patients randomised to elective coronary revascularisation plus medical therapy or medical therapy alone: a systematic review and meta-analysis. European Heart Journal. ehab246. Advance online publication. https://doi.org/10.1093/eurheartj/ehab246.

24. Nombela-Franco, L., Mitroi, C. D., Fernández-Lozano, I., García-Touchard, A., Toquero, J., Castro-Urda, V., Fernández-Diaz, J. A., Perez-Pereira, E., BeltránCorreas, P., Segovia, J., Werner, G. S., Javier, G. and Luis, A. P. 2012. Ventricular arrhythmias among implantable cardioverter-defibrillator recipients for primary prevention: impact of chronic total coronary occlusion (VACTO Primary Study). Circulation. Arrhythmia and Electrophysiology. 5(1), 147-154. 
25. Roth, G. A., Abate, D., Abate, K. H., Abay, S. M., Abbafati, C., Abbasi, N. et al. 2018. Global, regional, and national age-sex-specific mortality for 282 causes of death in 195 countries and territories, 1980-2017: a systematic analysis for the Global Burden of Disease Study. The Lancet. 392(10159), 1736-1788.

26. Roubin, G. S. 2014. The First Balloon Expandable Coronary Stent. University of Queensland Press. 61-68. ISBN 978-0-7022-5348-5.

27. Ruocco, N. A., Jr, Ring, M. E., Holubkov, R., Jacobs, A. K., Detre, K. M. and Faxon, D. P. 1992. Results of coronary angioplasty of chronic total occlusions (the National Heart, Lung, and Blood Institute 1985-1986 Percutaneous Transluminal Angioplasty Registry). The American Journal of Cardiology. 69(1), 69-76.

28. El Sabbagh, A., Patel, V. G., Jeroudi, O. M., Michael, T. T., Alomar, M. E., Mogabgab, O., Fuh, E., Roesle, M., Rangan, B. V., Abdullah, S., Hastings, J. L., Grodin, J., Kumbhani, D. J., Alexopoulos, D., Fasseas, P., Banerjee, S. and Brilakis, E. S. 2014. Angiographic success and procedural complications in patients undergoing retrograde percutaneous coronary chronic total occlusion interventions: a weighted meta-analysis of 3,482 patients from 26 studies. International Journal of Cardiology. 174(2), 243-248.

29. Shah, P. B. 2011. Management of coronary chronic total occlusion. Circulation. 123(16), 1780-1784. https://doi.org/10.1161/CIRCULATIONAHA.110.972802.

30. Stähli, B. E., Wischnewsky, M. B., Jakob, P., Klingenberg, R., Obeid, S., Heg, D., Räber, L., Windecker, S., Roffi, M., Mach, F., Gencer, B., Nanchen, D., Jüni, P., Landmesser, U., Matter, C. M., Lüscher, T. F. and Maier, W. 2018. Predictive value of the age, creatinine, and ejection fraction (ACEF) score in patients with acute coronary syndromes. International Journal of Cardiology. 270, 7-13.

31. Stein, J. H., Weiss, M. B., Ro, J. H., Herman, M. V. 1984. Percutaneous transluminal coronary angioplasty of a coronary artery with a total occlusion. Arch Intern Med. 144, 1875-1877.

32. Schumacher, S. P., Kockx, M., Stuijfzand, W. J., Driessen, R. S., van Diemen, P. A., Bom, M. J., Everaars, H., Raijmakers, P. G., Boellaard, R., van Rossum, A. C., Opolski, M. P., Nap, A. and Knaapen, P. 2021. Ischaemic burden and changes in absolute myocardial perfusion after chronic total occlusion percutaneous coronary intervention. EuroIntervention. 16(6), E471-E462.

33. Schumacher, S. P., Stuijfzand, W. J., de Winter, R. W., van Diemen, P. A., Bom, M. J., Everaars, H., Driessen, R. S., Kamperman, L., Kockx, M., Hagen, B., Raijmakers, P. G., van de Ven, P. M., van Rossum, A. C., Opolski, M. P., Nap, A. and Knaapen, P. 2021. Ischemic Burden Reduction and Long-Term Clinical Outcomes After Chronic Total Occlusion Percutaneous Coronary Intervention. JACC. Cardiovascular Interventions. 14(13), 1407-1418.

34. Surmely, J. F., Katoh, O., Tsuchikane, E., Nasu, K. and Suzuki, T. 2007. Coronary septal collaterals as an access for the retrograde approach in the percutaneous treatment of coronary chronic total occlusions. Catheterization and Cardiovascular Interventions. 69(6), 826-832. 
35. Surmely, J. F., Tsuchikane, E., Katoh, O., Nishida, Y., Nakayama, M., Nakamura, S., Oida, A., Hattori, E. and Suzuki, T. 2006. New concept for CTO recanalization using controlled antegrade and retrograde subintimal tracking: the CART technique. The Journal of Invasive Cardiology. 18(7), 334-338.

36. Tomasello, S. D., Boukhris, M., Giubilato, S., Marzà, F., Garbo, R., Contegiacomo, G., Marzocchi, A., Niccoli, G., Gagnor, A., Varbella, F., Desideri, A., Rubartelli, P., Cioppa, A., Baralis, G., Galassi, A. R. 2015. Management strategies in patients affected by chronic total occlusions: results from the Italian Registry of Chronic Total Occlusions. European Heart Journal. 36(45), 3189- 3198.

37. Usui, A., Abe, T., Araki, Y., Narita, Y., Mutsuga, M. \& Oshima, H. 2015. The number of cardiovascular surgeries in Japan may decrease after 2020. Nagoya Journal of Medical Science. 77(3), 389-398.

38. Werner, G. S., Martin-Yuste, V., Hildick-Smith, D., Boudou, N., Sianos, G., Gelev, V., Rumoroso, J. R., Erglis, A., Christiansen, E. H., Escaned, J., di Mario, C., Hovasse, T., Teruel, L., Bufe, A., Lauer, B., Bogaerts, K., Goicolea, J., Spratt, J. C., Gershlick, A. H., Galassi, A. R. and EUROCTO trial investigators. 2018. A randomized multicentre trial to compare revascularization with optimal medical therapy for the treatment of chronic total coronary occlusions. European Heart Journal. 39(26), 2484-2493. 


\section{Pateicības}

Vēlos izteikt visdziḷāko pateicību par morālo atbalstu un profesionālo palīdzību daudzu gadu garumā darba vadītājiem Dr. med. LZA īstenajam loceklim profesoram Aivaram Lejniekam, Dr. med. LZA īstenajam loceklim profesoram Andrejam Ērglim, konsultantei statistikas jautājumos asociētajai profesorei Ievai Strēlei.

Liels paldies par morālo atbalstu asociētajai profesorei Ilzei Konrādei.

Liels paldies RAKUS Sirds asinsvadu slimību klīnikas kolektīvam un īpaši Invazīvās kardioloǵijas laboratorijas un dienas stacionāra darbiniekiem ārstiem, māsām.

Sirsnīgs paldies pacientiem par piekrišanu piedalīties pētījumā.

Vissirsnīgākais paldies un pateicība manai sievai Intai, dēlam Kristapam par sapratni, atbalstu un rūpēm. 